\title{
Role of Mixed Oxides in Hydrogen Production through the Dry Reforming of Methane over Nickel Catalysts Supported on Modified $\gamma-\mathrm{Al}_{2} \mathrm{O}_{3}$
}

\author{
Ahmed Sadeq Al-Fatesh 1,*D , Mayankkumar Lakshmanbhai Chaudhary ${ }^{2}$, Anis Hamza Fakeeha 1,3 ${ }^{\mathbb{D}}$, \\ Ahmed Aidid Ibrahim ${ }^{1}$ (D), Fahad Al-Mubaddel 1,3 ${ }^{1}$, Samsudeen Olajide Kasim ${ }^{1}$ (D), \\ Yousef Abdulrahman Albaqmaa ${ }^{1} \mathbb{D}$, Abdulaziz A. Bagabas ${ }^{4} \mathbb{D}$, Rutu Patel ${ }^{2}$ and Rawesh $\operatorname{Kumar}^{2} \mathbb{D}$
}

check for

updates

Citation: Al-Fatesh, A.S.; Chaudhary, M.L.; Fakeeha, A.H.; Ibrahim, A.A.; Al-Mubaddel, F.; Kasim, S.O.; Albaqmaa, Y.A.; Bagabas, A.A.; Patel,

R.; Kumar, R. Role of Mixed Oxides in Hydrogen Production through the Dry Reforming of Methane over Nickel Catalysts Supported on Modified $\gamma-\mathrm{Al}_{2} \mathrm{O}_{3}$. Processes 2021, 9 , 157. https://doi.org/10.3390/ pr9010157

Received: 15 December 2020 Accepted: 8 January 2021 Published: 15 January 2021

Publisher's Note: MDPI stays neutral with regard to jurisdictional clai$\mathrm{ms}$ in published maps and institutional affiliations.

Copyright: (C) 2021 by the authors. Licensee MDPI, Basel, Switzerland. This article is an open access article distributed under the terms and conditions of the Creative Commons Attribution (CC BY) license (https:// creativecommons.org/licenses/by/ $4.0 /)$.
1 Chemical Engineering Department, College of Engineering, King Saud University, P.O. Box 800, Riyadh 11421, Saudi Arabia; anishf@ksu.edu.sa (A.H.F.); aididwthts2011@gmail.com (A.A.I.); falmubaddel@ksu.edu.sa (F.A.-M.); sofkolajide2@gmail.com (S.O.K.); youssef201629@gmail.com (Y.A.A.)

2 Sankalchand Patel University, Visnagar 384315, India; mayankchaudhary8326@gmail.com (M.L.C.); rutupatel1145@gmai.com (R.P.); kr.rawesh@gmail.com (R.K.)

3 King Abdullah City for Atomic \& Renewable Energy, Energy Research \& Innovation Center (ERIC) in Riyadh, Riyadh 11451, Saudi Arabia

4 National Petrochemical Technology Center (NPTC), Materials Science Research Institute (MSRI), King Abdulaziz City for Science and Technology (KACST), P.O. Box 6086, Riyadh 11442, Saudi Arabia; abagabas@hotmail.com

* Correspondence: aalfatesh@ksu.edu.sa; Tel.: +966-11-467-6859

\begin{abstract}
H}_{2}$ production through dry reforming of methane (DRM) is a hot topic amidst growing environmental and atom-economy concerns. Loading Ni-based reducible mixed oxide systems onto a thermally stable support is a reliable approach for obtaining catalysts of good dispersion and high stability. Herein, $\mathrm{NiO}$ was dispersed over $\mathrm{MO}_{\mathrm{x}}$-modified- $\gamma-\mathrm{Al}_{2} \mathrm{O}_{3}(\mathrm{M}=\mathrm{Ti}, \mathrm{Mo}, \mathrm{Si}$, or $\mathrm{W} ; \mathrm{x}=2$ or 3) through incipient wetness impregnation followed by calcination. The obtained catalyst systems were characterized by infrared, ultraviolet-visible, and X-ray photoelectron spectroscopies, and $\mathrm{H}_{2}$ temperature-programmed reduction. The mentioned synthetic procedure afforded the proper nucleation of different $\mathrm{NiO}$-containing mixed oxides and/or interacting-NiO species. With different modifiers, the interaction of $\mathrm{NiO}$ with the $\gamma-\mathrm{Al}_{2} \mathrm{O}_{3}$ support was found to change, the $\mathrm{Ni}^{2+}$ environment was reformed exclusively, and the tendency of $\mathrm{NiO}$ species to undergo reduction was modified greatly. Catalyst systems $5 \mathrm{Ni} 3 \mathrm{MAl}(\mathrm{M}=\mathrm{Si}, \mathrm{W})$ comprised a variety of species, whereby $\mathrm{NiO}$ interacted with the modifier and the support (e.g., $\mathrm{NiSiO}_{3}, \mathrm{NiAl}_{2} \mathrm{O}_{4}$, and $\mathrm{NiWO}_{3}$ ). These two catalyst systems displayed equal efficiency, $>70 \% \mathrm{H}_{2}$ yield at $800{ }^{\circ} \mathrm{C}$, and were thermally stable for up to $420 \mathrm{~min}$ on stream. $5 \mathrm{Ni3SiAl}$ catalyst regained nearly all its activity during regeneration for up to two cycles.
\end{abstract}

Keywords: $\mathrm{H}_{2}$ production; mixed oxide; $\mathrm{NiAl}_{2} \mathrm{O}_{4} ; \mathrm{NiWO}_{3} ; \mathrm{NiSiO}_{3} ; \mathrm{NiO}$-interacting species

\section{Introduction}

Hydrogen $\left(\mathrm{H}_{2}\right)$ is a green energy source. In fact, the energy content of this molecule is three times higher than that of gasoline [1]. $\mathrm{H}_{2}$ is a critical feedstock for the chemical industry in oil refining, fertilizer production, and fuel cell manufacture [2]. Notably, biomass pyrolysis and biomass gasification have always been environmentally questionable approaches to hydrogen production; moreover, the implementation of these methods renders $\mathrm{H}_{2}$ isolation and purification quite difficult, as the desired product associates with many side-products [3]. A more convenient approach is hydrogen production from compounds such as ethanol [4], glycerol [5], glucose [6], starch, and catechol [7], by steam or thermal reforming over a heterogeneous catalyst. Environmental concerns and the high demand for atom-economies have driven the development of hydrogen production methods, relying 
on clean sources, such as water splitting, thermal reforming of methane, stream reforming of methane, and $\mathrm{CO}_{2}$ (dry) reforming of methane (DRM) [8,9]. DRM in particular, has drawn great deal of attention globally because it fulfils the goal of hydrogen production while raising hope for the reduction of the atmospheric concentrations of carbon dioxide and methane, the two gases whose emissions are most responsible for global warming.

From a catalytic standpoint, metal oxide and mixed metal oxide systems have attracted the attention of the industry, due to their ease of formation, development of mixed oxide potential, tuneable surface topology, high temperature sustainability, and ease of handling in drastic industrial conditions [10]. Ni-based catalysts supported on thermally-stable neutral $\mathrm{SiO}_{2}$ [11], acidic $\mathrm{Al}_{2} \mathrm{O}_{3}$ [12], and reducible $\mathrm{TiO}_{2}$ [13,14] have been investigated thoroughly in recent years. Due to the need of acid-base bi-functional catalyst for DRM, $\mathrm{TiO}_{2}$ and $\mathrm{Al}_{2} \mathrm{O}_{3}$ supports were investigated more than $\mathrm{SiO}_{2}$. Reducibility characteristics of $\mathrm{TiO}_{2}$ controls the coke deposition. However, the coverage of Ni species by the $\mathrm{TiO}_{\mathrm{x}}$ and partial transformation of amorphous titania phase into the anatase phase limit its DRM application [15]. Nevertheless, the addition of $25 \% \mathrm{Al}_{2} \mathrm{O}_{3}$ to $\mathrm{TiO}_{2}$ support was found to be beneficial [16]. Overall, the highly thermal stability, low cost, wide availability, and strong metal-support interaction favor alumina as the support for Ni dispersion [17]. Nickel form bulk $\mathrm{NiO}$ is sintered into large $\mathrm{Ni}$ particles during DRM, and these nanoparticles are encapsulated by carbon. Due to encapsulation and loss of catalytic active sites, the catalytic activity was affected badly [18]. Alumina supported Nickel catalyst system has mixed oxide $\mathrm{NiAl}_{2} \mathrm{O}_{4}$ phases, confirming strong metal-support interaction in the catalyst system. Reduced $\mathrm{Ni}$ derived from $\mathrm{NiAl}_{2} \mathrm{O}_{4}$ favors the formation of carbon filament by putting the Ni particle on tip. Therefore, it showed high resistant to sintering and coking without affecting the catalytic activity. $\mathrm{Al}_{2} \mathrm{O}_{3}$ nanosheet provides superior anchoring surface (100) for Ni nanoparticle and so Ni-based catalysts supported on nanosheet (S) were claimed to result in more than $85 \% \mathrm{CO}_{2}$ and $\mathrm{CH}_{4}$ conversion with excellent $\mathrm{H}_{2}$ and $\mathrm{CO}$ selectivity [19]. However, Ni-based catalysts supported on nanofiber exhibited superior catalytic stability due to its abundant confined spaces and steady chemisorption behavior. Under other synthetic methodology, such as evaporation-induced self-assembly method [20] and microwave-assisted combustion [21] and atomic layer deposition [22] method have drawn attentions. As a sandwiched catalyst $\mathrm{Al}_{2} \mathrm{O}_{3} / \mathrm{Ni} / \mathrm{Al}_{2} \mathrm{O}_{3}$ (prepared by atomic layer deposition) prevented $\mathrm{Ni}$ gathering over alumina by coating of porous $\mathrm{Al}_{2} \mathrm{O}_{3}$ thin-film over $\mathrm{Ni} / \mathrm{Al}_{2} \mathrm{O}_{3}$. Moreover, $\mathrm{Ni}$ had double interaction with $\mathrm{Al}_{2} \mathrm{O}_{3}$ in this catalyst system and so it was claimed nearly $100 \% \mathrm{CO}_{2}$ and $\mathrm{CH}_{4}$ conversion with absolute selectivity towards $\mathrm{CO}$ and $\mathrm{H}_{2}$.

Incorporation of $\mathrm{Cu}, \mathrm{Mo}, \mathrm{Si}, \mathrm{Sr}, \mathrm{B}, \mathrm{Ca}, \mathrm{Mg}, \mathrm{Ba}, \mathrm{Ga}, \mathrm{Gd}, \mathrm{Zn}, \mathrm{Ti}, \mathrm{W}, \mathrm{Mn}, \mathrm{Co}, \mathrm{Zr}, \mathrm{Ce}, \mathrm{La}$, and $\mathrm{Yb}$, in the alumina supported $\mathrm{Ni}$ catalyst was examined in the search of high catalytic activity and coke resistance. The addition of $\mathrm{Cu}$ resulted in inferior performance due to sintering of $\mathrm{Cu}$ particles and presence of free $\mathrm{NiO}$ (weak metal support interaction) $[23,24]$. The inferior performance of Mo promoted $\mathrm{Ni} / \mathrm{Al}_{2} \mathrm{O}_{3}$ catalyst was due to weak metal support interaction, the formation of $\mathrm{MoNi}_{4}$ phase and the lower basicity of catalyst [25]. Modification of $\mathrm{Ni} / \mathrm{Al}_{2} \mathrm{O}_{3}$ with $11.9 \mathrm{wt} \% \mathrm{~W}$ modified $\mathrm{Ni} / \mathrm{Al}_{2} \mathrm{O}_{3}$ showed $76 \%$ less carbon decomposition than unmodified samples [26]. It was supposed that $\mathrm{Ni}-\mathrm{W}$ alloy formed during reduction and hindered the carbon deposition inside the lattice and further tungsten carbide formed and carried out carbon gasification. However, Ni.W alloy formation caused inferior catalytic activity because alloy might be less active for methane decomposition. Monolithic Ni- $\mathrm{Al}_{2} \mathrm{O}_{3}-\mathrm{SiC}$ catalyst was claimed higher $\mathrm{CO}_{2}$ conversion $(>40 \%)$ and $\mathrm{CH}_{4}$ conversion $(\sim 30 \%)$ than $\mathrm{Ni} / \mathrm{Al}_{2} \mathrm{O}_{3}$ catalyst due to stereo-structure and highly dispersed $\mathrm{Ni}$ species [27]. The addition of $0.75 \mathrm{wt} \% \mathrm{Sr}$ addition improved the metal (Ni) support $\left(\mathrm{Al}_{2} \mathrm{O}_{3}\right)$ interaction and boosts Lewis basicity. It favored $\mathrm{CO}_{2}$ absorption and dissociation which in turn decreased the coke deposition [28]. Modification of 0.6-5.6 wt $\% \mathrm{~B}_{2} \mathrm{O}_{3}$ led to size-reduction of Ni particles which induced $74-86 \%$ less coke formation during DRM without significantly affecting activity and selectivity [29]. Among the basic modifier: $\mathrm{MgO}$, $\mathrm{CaO}$ and $\mathrm{BaO}$; it was found that $3 \mathrm{wt} \% \mathrm{MgO}$ addition improved the catalytic activity $(>70 \%$ 
$\mathrm{CH}_{4}$ and $\mathrm{CO}_{2}$ conversion up to $300 \mathrm{~min}$ ) due to formation of $\mathrm{MgAl}_{2} \mathrm{O}_{4}$ mixed oxide [30]. Promotional addition of $\mathrm{Ga}$, $\mathrm{Gd}$ and $\mathrm{Zn}$ claimed high $\mathrm{CH}_{4}$ and $\mathrm{CO}_{2}$ conversions (close to $80 \%$ during 420 min time on stream) with $\mathrm{H}_{2} / \mathrm{CO}=1.0$ due to content of $\mathrm{NiO}$ interacted moderately and strongly with the support [24]. Co-addition to $\mathrm{Ni} / \mathrm{Al}_{2} \mathrm{O}_{3}$ nano catalyst showed high $\mathrm{Ni} / \mathrm{Al}$ ratio than $\mathrm{Ni} / \mathrm{Al}_{2} \mathrm{O}_{3}$ which led to better $\mathrm{Ni}$ dispersion over the alumina surface (by reducing the ensemble size of $\mathrm{Ni}$ ) [23]. It was claimed good catalytic activity $\left(\mathrm{CO}_{2}\right.$ and $\mathrm{CH}_{4}$ conversion $>80 \%$ at $\left.750{ }^{\circ} \mathrm{C}\right)$ with $\mathrm{H}_{2} / \mathrm{CO}$ ratio was close to one and less coke deposition. Mn-addition caused partial blockage of large Ni particle which was assumed for rapid coke formation. Further addition of potassium caused stability in activity [31]. $\mathrm{ZrO}_{2}$ addition enhanced the dissociation of $\mathrm{CO}_{2}$ near the contact between $\mathrm{ZrO}_{2}$ and nickel where the deposited coke was gasified afterwards [32]. Optimum ceria addition caused formation of $\mathrm{CeAlO}_{3}$ mixed phase. Ceria added mobile lattice oxygen in the surface reaction mechanism of DRM which endorsed minimum coking [33,34]. The addition of lanthana enhanced Ni stability and alkalinity of catalyst [35]. Alkalinity caused profound carbon dioxide adsorption, activation and oxidation of carbon deposit. The addition of $1-2 \mathrm{wt} \% \mathrm{Yb}$ in NiO-containing $\mathrm{Al}_{2} \mathrm{O}_{3}$ (prepared by sol-gel process) matrix controlled the size/mobility of Ni nanoparticles. Moreover, the high ease of reducibility and low carbon deposition led to high catalytic activity and catalyst stability $\left(\mathrm{CH}_{4}\right.$ conversions $75-81.5 \%$ and $\mathrm{CO}_{2}$ conversions $83.5-89 \%$ for $22 \mathrm{~h}$ time on stream), and $\mathrm{H}_{2} / \mathrm{CO}$ close to unity ( 0.95) [36]. The active elements in doped/promoted $\mathrm{Al}_{2} \mathrm{O}_{3}$-supported Ni catalyst systems are presented as the color blocks in periodic table in Figure 1.

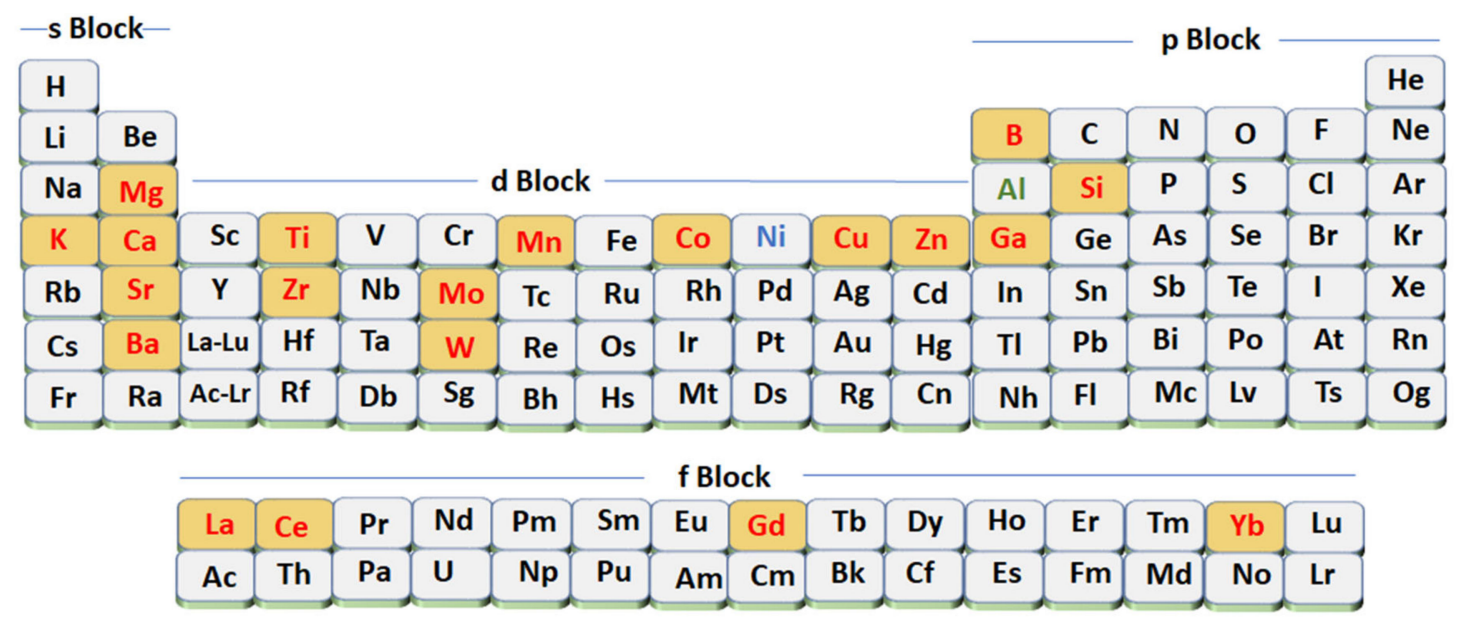

Figure 1. Active elements in a doped/promoted $\mathrm{Al}_{2} \mathrm{O}_{3}$-supported Ni catalyst system for dry reforming of methane.

In these systems, apart from the dispersed, stable $\mathrm{NiO}$, other $\mathrm{Ni}$-containing phases, like $\mathrm{Ni}_{2} \mathrm{SiO}_{4}, \mathrm{NiAl}_{2} \mathrm{O}_{4}, \mathrm{MgAl}_{2} \mathrm{O}_{4}, \mathrm{CeAlO}_{3}, \mathrm{NiTiO}_{3}$, and $\mathrm{Ni}_{2} \mathrm{TiO}_{4}$, have also been detected. The presence of $\mathrm{NiWO}_{4}$ [37] and $\mathrm{NiMoO}_{4}$ species [38] has also been reported in Ni-based catalysts supported on $\mathrm{WC}_{\mathrm{x}}$ or $\mathrm{MoC}_{\mathrm{x}}$, respectively, for DRM. In this context, understanding the role played by different metal oxides or mixed metal oxides matrices in the production of hydrogen through DRM is imperative. Recently, we prepared a modified $\gamma-\mathrm{Al}_{2} \mathrm{O}_{3}$ support by incipient wetness impregnation followed by calcination; notably, the modifier was loaded as $3.0 \mathrm{wt} \% \mathrm{MO}_{\mathrm{x}}(\mathrm{M}=\mathrm{W}, \mathrm{Mo}, \mathrm{Si}$, or Ti; $\mathrm{x}=2$ or 3) [39]. The active Ni catalyst was then loaded onto the modified $\gamma-\mathrm{Al}_{2} \mathrm{O}_{3}$ support by incipient wetness impregnation, followed by calcination to reach $5.0 \mathrm{wt} \% \mathrm{NiO}$ loading. The catalysts, thus obtained, are abbreviated as $5 \mathrm{Ni} 3 \mathrm{MAl}(\mathrm{M}=\mathrm{W}, \mathrm{Mo}, \mathrm{Si}$, or Ti). This synthetic strategy gave the chance of interaction of all types of oxides and, hence, the formation of mixed metal oxides. The study of this type of catalytic systems may provide information that would help understand the role of metal oxides and mixed metal oxides in DRM. Herein, we report the preparation of the $5 \mathrm{Ni} 3 \mathrm{MAl}(\mathrm{M}=\mathrm{W}, \mathrm{Mo}, \mathrm{Si}$, or Ti) catalyst systems, their characterization by infrared (IR), ultraviolet-visible (UV-Vis), X-ray photoelectron (XPS) spectroscopies, 
and by $\mathrm{H}_{2}$ temperature-programmed reduction $\left(\mathrm{H}_{2}\right.$-TPR). We also report the results of tests run on these systems for $\mathrm{H}_{2}$ production. We attempted to identify the metal, metal oxides, and mixed metal oxides responsible for $\mathrm{H}_{2}$ production through DRM. Crucially, this information would be useful in the design of metal oxide matrix catalyst systems suitable for the industrial production of $\mathrm{H}_{2}$ through DRM.

\section{Results}

\subsection{Catalytic Activity}

Data reflecting the catalytic activity of the prepared catalysts, in terms of $\mathrm{H}_{2}$ yield over $420 \mathrm{~min}$ on stream at $700{ }^{\circ} \mathrm{C}$ are reported in Figure $2 \mathrm{~A}$. On the other hand, Figure 2B shows values for the $\mathrm{H}_{2}$ yield at different reaction temperatures. Among the investigated catalysts, $5 \mathrm{Ni} 3 \mathrm{SiAl}$ and $5 \mathrm{Ni} 3 \mathrm{WAl}$ exhibited the highest catalytic performance, and the activities and stabilities of these two species were found to be identical. The $\mathrm{H}_{2}$ yield recorded for both catalysts over $420 \mathrm{~min}$ on stream was about $62 \%$ at $700{ }^{\circ} \mathrm{C}$. The $\mathrm{H}_{2}$ yield over $5 \mathrm{Ni} 3 \mathrm{MoAl}$ catalyst was $47 \%$ after $20 \mathrm{~min}$ on stream, which decreased to $39 \%$ after $420 \mathrm{~min}$ on stream. The catalytic performance of $5 \mathrm{Ni3TiAl}$ was found to be the worst: $\sim 30 \% \mathrm{H}_{2}$ yield after 420 min on stream. Notably, the $\mathrm{H}_{2}$ yield in the presence of all catalyst systems increased as the reaction temperature increased. At $800{ }^{\circ} \mathrm{C}$, the use of $5 \mathrm{Ni} 3 \mathrm{SiAl}$ and $5 \mathrm{Ni} 3 \mathrm{WAl}$ was associated with more than $70 \% \mathrm{H}_{2}$ yield, whereas in the case of $5 \mathrm{Ni} 3 \mathrm{MoAl}$ and $5 \mathrm{Ni} 3 \mathrm{TiAl}, \mathrm{H}_{2}$ yield was measured to be around $60 \%$. Higher conversion trend at higher temperature indicated the endothermic nature of DRM reaction. For silicon- or tungsten-modified alumina-supported nickel catalyst system, the rise of $\mathrm{H}_{2}$ yield with temperature were similar. For titanium- and molybdenum-modified catalyst systems, the rise of $\mathrm{H}_{2}$ yield with temperature were similar up to $650{ }^{\circ} \mathrm{C}$, and after this temperature, molybdenum-modified catalyst system showed better $\mathrm{H}_{2}$ yield.
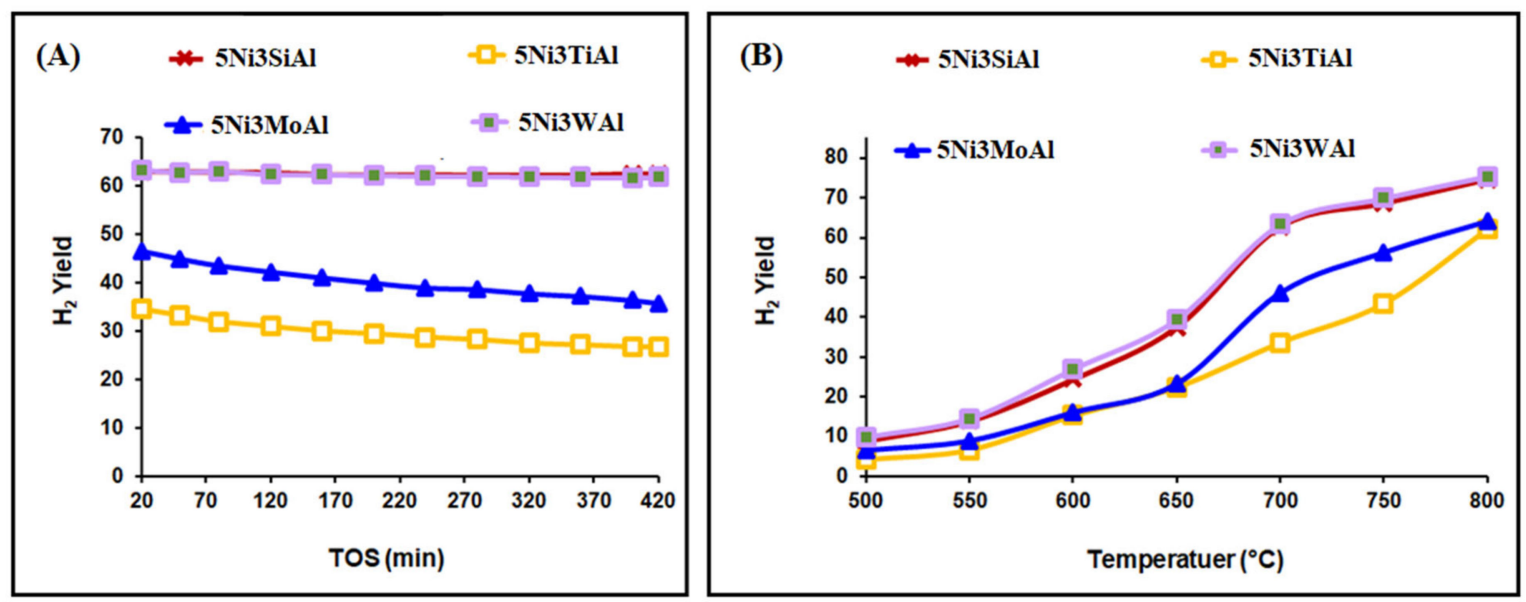

Figure 2. (A) $\mathrm{H}_{2}$ yield over different catalyst systems up to $420 \mathrm{~min}$ TOS at $700{ }^{\circ} \mathrm{C}$; (B) $\mathrm{H}_{2}$ yield over different catalyst systems in the $500-800{ }^{\circ} \mathrm{C}$ reaction temperature range.

\subsection{Result}

SEM images and EDX patterns of 5Ni3MAl $(\mathrm{M}=\mathrm{W}, \mathrm{Si}, \mathrm{Mo}, \mathrm{Ti})$ are shown in Figures S1 and S2, respectively. EDX patterns showed the presence of all claimed elements in the catalyst systems (Figure S2). In all IR spectra, the sharp peak at $1644 \mathrm{~cm}^{-1}$ and the broad intense peak at $3450 \mathrm{~cm}^{-1}$ could be due to the bending and stretching vibrations, respectively, of adsorbed water molecules or surface hydroxyl groups [40]. The IR peaks in the $600-750 \mathrm{~cm}^{-1}$ wavenumber range could be attributed to the vibrations of $\mathrm{AlO}_{6}$ octahedral units (Al-O bonds in an octahedral environment), whereas those in the $750-850 \mathrm{~cm}^{-1}$ range could be attributed to $\mathrm{AlO}_{4}$ tetrahedral units (Al-O bonds in a tetrahedral environment) [41]. The three peaks in the $1640-1350 \mathrm{~cm}^{-1}$ wavenumber range 
might be assigned to the bending vibration of the water molecules coordinated to different unsaturated surface sites. Furthermore, the peak at $1635 \mathrm{~cm}^{-1}$ could be due to the vibration of physically adsorbed water molecules, whereas the peak at $1380 \mathrm{~cm}^{-1}$ could be due to the bending vibration of water molecules coordinating tetrahedral aluminum [40]. The IR spectrum of $\gamma-\mathrm{Al}_{2} \mathrm{O}_{3}$ was characterized by the presence of three peaks at $1635 \mathrm{~cm}^{-1}$, $1517 \mathrm{~cm}^{-1}$, and $1382 \mathrm{~cm}^{-1}$ [42]. IR peaks in the $400-470 \mathrm{~cm}^{-1}$ wavenumber range could be due to the vibration of the $\mathrm{Ni}-\mathrm{O}$ bond [43] in free $\mathrm{NiO}$ or to the said bond in mixed oxides such as $\mathrm{NiSiO}_{4}, \mathrm{NiAl}_{2} \mathrm{O}_{4}, \mathrm{NiTiO}_{3}, \mathrm{NiWO}_{4}$, and $\mathrm{NiMoO}_{4}$. The IR spectrum of the titanium-modified catalyst sample, 5Ni3TiAl, (Figure 3A,B and Figure S3A,B), comprised an absorption peak at $433 \mathrm{~cm}^{-1}$, which could be due to the $\mathrm{Ni}-\mathrm{O}$ vibration of free $\mathrm{NiO}$ species in a cubic lattice, and peaks at $455 \mathrm{~cm}^{-1}$ and $547 \mathrm{~cm}^{-1}$, which may be due to the $\mathrm{Ni}-\mathrm{O}$ bond vibration of $\mathrm{NiTiO}_{3}[44,45]$. After $\mathrm{NiO}$ loading, the peak due to $\mathrm{TiO}_{2}$ in the low-frequency region of the spectrum (below $500 \mathrm{~cm}^{-1}$ ) was replaced by peaks due to $\mathrm{Ni}-\mathrm{O}$ vibrations, which was an indication of the extent of interaction of $\mathrm{NiO}$ species with the modifier over the support.

The IR spectrum of the molybdenum-containing catalyst, 5Ni3MoAl, (Figure 3C,D and Figure S3A,B), comprised a band at $424 \mathrm{~cm}^{-1}$ due to $\mathrm{Ni}-\mathrm{O}$ bond vibration, which appeared at lower wavenumber values than that attributed to free $\mathrm{NiO}\left(433 \mathrm{~cm}^{-1}\right)$ in the spectrum of the titanium-modified catalyst. No other prominent peaks due to Ni-O vibrations were noticed in the spectrum of the molybdenum-containing catalyst, indicating the deformation of cubic $\mathrm{NiO}$ species and the formation of species, whereby $\mathrm{NiO}$ interacted with the support, the modifier, or both [46,47]. After $\mathrm{NiO}$ loading, the peak due to $\mathrm{MoO}_{\mathrm{x}}$ in the low-frequency region was completely replaced by the vibrational peak of Ni-O, indicating the extent of the interaction of $\mathrm{NiO}$ species with the modifier over the support.

In the IR spectrum of $5 \mathrm{Ni3SiAl}$ (Figure 3E,F and Figure S3A,B), Ni-O vibrational peaks at $430 \mathrm{~cm}^{-1}$, due to free $\mathrm{NiO}$, and $403 \mathrm{~cm}^{-1}$, due to strongly interacting-NiO (as a result of the weakening of the Ni-O bond), were noticed, alongside a peak at $453 \mathrm{~cm}^{-1}$, due to the Si-O-Si bending vibration [48], and one at $481 \mathrm{~cm}^{-1}$, due to the asymmetric vibration of $\mathrm{Si}-\mathrm{O}$ [49]. However, the S-O asymmetric vibration peak was not noticed in the spectrum of $\mathrm{SiO}_{2}-\mathrm{Al}_{2} \mathrm{O}_{3}$, indicating that this vibration was related to an interaction of $\mathrm{NiO}$ with silica species or to the presence of amorphous nickel silicate species. This finding is in agreement with our previous claim of an interaction of $\mathrm{NiO}$ species, as deduced from $\mathrm{H}_{2}$-TPR data, and the absence of nickel silicate phases, as deduced from $\mathrm{X}$-ray diffraction data. The IR peak and its shoulder appearing in the $549-560 \mathrm{~cm}^{-1}$ wavenumber range could be attributed to the presence of Al-O-Ni bonding interactions in $\mathrm{NiAl}_{2} \mathrm{O}_{4}$ [50].

In both $5 \mathrm{Ni3SiAl}$ and $5 \mathrm{Ni} 3 \mathrm{WAl}$, following $\mathrm{NiO}$ loading, the infrared spectra of the modified catalysts became populated with intense peaks, indicating the presence and dispersion of a wide variety of species, whereby $\mathrm{NiO}$ interacted with catalyst components on the catalyst surface. In the IR spectrum of $5 \mathrm{NiWAl}$ (Figure $3 \mathrm{G}, \mathrm{H}$ ) the low-intensity absorption bands below $500 \mathrm{~cm}^{-1}$ could be attributed to the stretching vibrations of $\mathrm{NiO}_{6}$ polyhedral in $\mathrm{NiWO}_{4}$ species [51].

The infrared spectra of the catalyst samples showed a clear shift of Ni-O peak from $433 \mathrm{~cm}^{-1}$ (for $5 \mathrm{Ni} 3 \mathrm{TiAl}$ ) to $424 \mathrm{~cm}^{-1}$ (for $5 \mathrm{Ni} 3 \mathrm{MoAl}$ ) and $403 \mathrm{~cm}^{-1}$ (for $5 \mathrm{Ni} 3 \mathrm{SiAl}$ ). That reflects the presence of "free $\mathrm{NiO}$ " species in $5 \mathrm{Ni} 3 \mathrm{TiAl} ; \mathrm{NiO}$ species interacted with the modifier in $5 \mathrm{Ni} 3 \mathrm{MoAl}$ and $\mathrm{NiO}$ species strongly interacted with the support/modifier in $5 \mathrm{Ni3SiAl}$. 5Ni3WAl catalyst samples had a wide interaction $\mathrm{NiO}$ species as it showed stretching vibration of $\mathrm{NiO}_{6}$ polyhedral. 

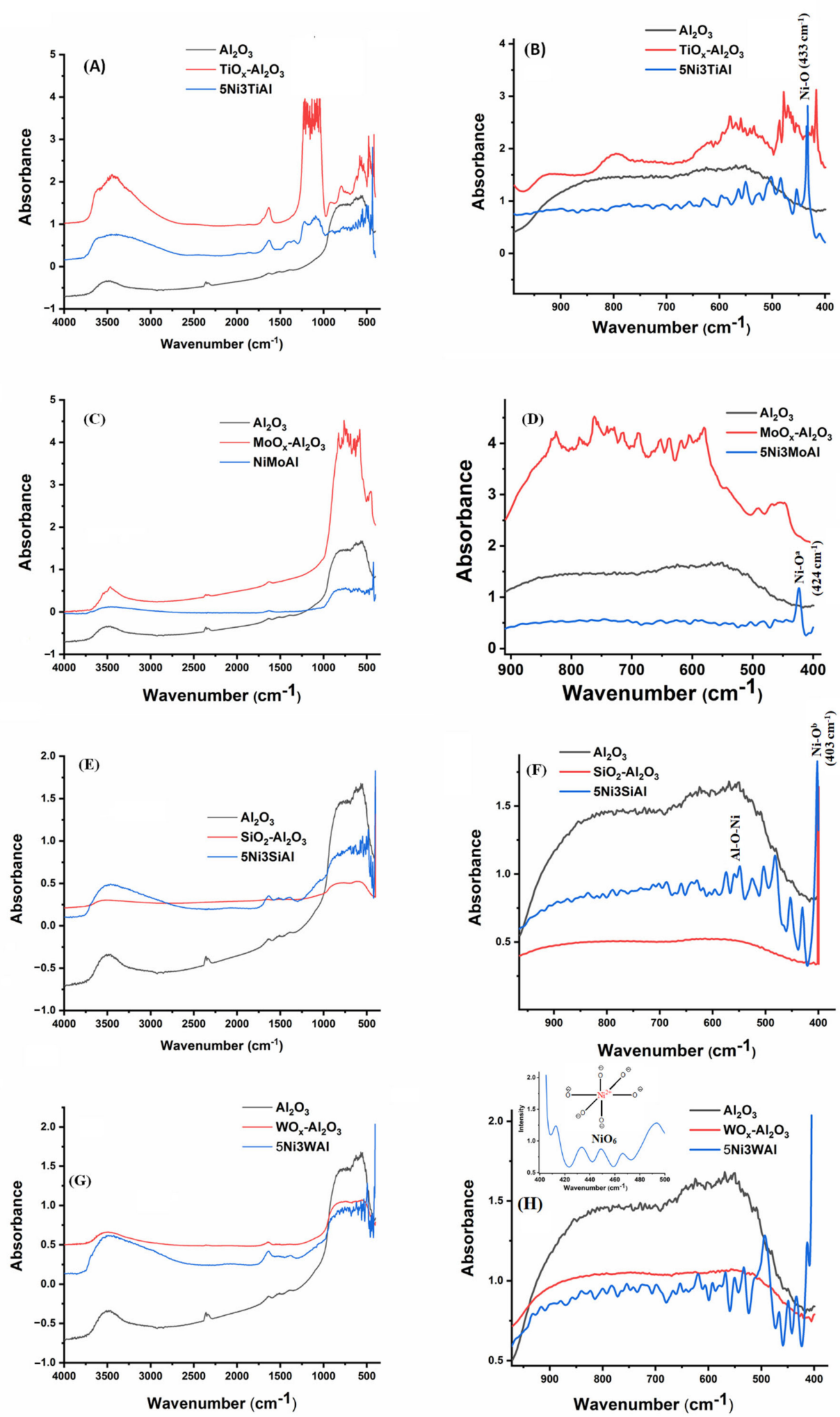

Figure 3. (A-H) Infrared spectra of different catalyst systems. In (D), $\mathrm{Ni}-\mathrm{O}^{\mathrm{a}}$ indicates $\mathrm{NiO}$ species that interacted with the support. In $(\mathbf{F}) \mathrm{Ni}^{-} \mathrm{O}^{\mathrm{b}}$ indicates $\mathrm{NiO}$ species that strongly interacted with the support. In $(\mathbf{H})$ inset indicates stretching vibration peaks of $\mathrm{NiO}_{6}$ polyhedra in $\mathrm{NiWO}_{4}$ species. 
UV-Vis spectroscopy is the most suitable characterization technique to understand the electronic environment of $\mathrm{Ni}^{2+}$ or $\mathrm{d}^{8}$-configuration systems. The UV-Vis absorption spectra of all catalyst samples are reported in Figure 4. The peak observed at 250-350 nm is associated with the charge transfer transition from $\mathrm{O}^{2-}$ to $\mathrm{Ni}^{2+}$ in an octahedral coordination environment $\left(\mathrm{O}^{2-} \rightarrow \mathrm{Ni}^{2+}\right)$ in the $\mathrm{NiO}$ lattice [29]. The peak centered at around $410 \mathrm{~nm}$ is associated with the d-d transition from the ${ }^{3} \mathrm{~A}_{2 \mathrm{~g}}(\mathrm{~F})$ state to the ${ }^{3} \mathrm{~T}_{1 \mathrm{~g}}(\mathrm{P})$ state of $\mathrm{Ni}^{2+}$ in an octahedral environment, whereas the doublet peak with maxima at $593 \mathrm{~nm}$ and $634 \mathrm{~nm}$ were attributed to the $\mathrm{d}$-d transition from the ${ }^{3} \mathrm{~T}_{1}(\mathrm{~F})$ state to the ${ }^{3} \mathrm{~T}_{1}(\mathrm{P})$ state of $\mathrm{Ni}^{2+}$ in a tetrahedral environment [52]. Among all four catalysts, only the silicon- and tungsten-containing catalysts (5Ni3SiAl and $5 \mathrm{Ni} 3 \mathrm{WAl}$ ) included $\mathrm{Ni}^{2+}$ ions in both tetrahedral and octahedral environments. The $\mathrm{NiAl}_{2} \mathrm{O}_{4}$ phase is known to comprise $\mathrm{Ni}^{2+}$ ions in both tetrahedral and octahedral coordination environments. Therefore, $5 \mathrm{Ni3SiAl}$ and $5 \mathrm{Ni3WAl}$ may contain $\mathrm{NiAl}_{2} \mathrm{O}_{4}$ phases. In the case of the other catalysts, the mentioned bands either displayed low intensity or had shifted toward higher wavelengths, indicating a weak interaction between the modifier and $\mathrm{Ni}^{2+}$ and the support. In the case of the titanium-containing catalyst ( $5 \mathrm{Ni} 3 \mathrm{TiAl})$, no peaks attributable to $\mathrm{Ni}^{2+}$ ions in tetrahedral environments were observed, indicating the absence of an $\mathrm{NiAl}_{2} \mathrm{O}_{4}$ phase. By contrast, the UV-Vis spectrum of $5 \mathrm{Ni} 3 \mathrm{TiAl}$ displayed a peak at $740 \mathrm{~nm}$ attributable to $\mathrm{Ni}^{2+}$ in an octahedral coordination environment, as segregated or crystallized $\mathrm{NiO}$ which was as near as bulk $\mathrm{NiO}$ [53], indicating that octahedral coordinated $\mathrm{Ni}^{2+}$ was present in segregated form in 5Ni3TiAl. An additional hump in the 260-330 nm wavelength range for 5Ni3TiAl could be assigned to a charge transfer from $\mathrm{O}^{2-}$ to octahedral/tetrahedral $\mathrm{Ti}^{4+}\left(\mathrm{O}^{2-} \rightarrow \mathrm{Ti}^{4+}\right)$ in a possible $\mathrm{NiTiO}_{3}$ phase [44]. The hump in the 280-330 nm wavelength range observed in the UV-Vis spectrum of $5 \mathrm{NiMoAl}$ could be attributed to a charge transfer from $\mathrm{O}^{2-}$ to octahedral/tetrahedral $\mathrm{Mo}^{6+}\left(\mathrm{O}^{2-} \rightarrow \mathrm{Mo}^{6+}\right)$ in a possible $\mathrm{NiMoO}$ phase $/ \mathrm{Al}_{2}\left(\mathrm{MoO}_{4}\right)_{3}$ phase [54].

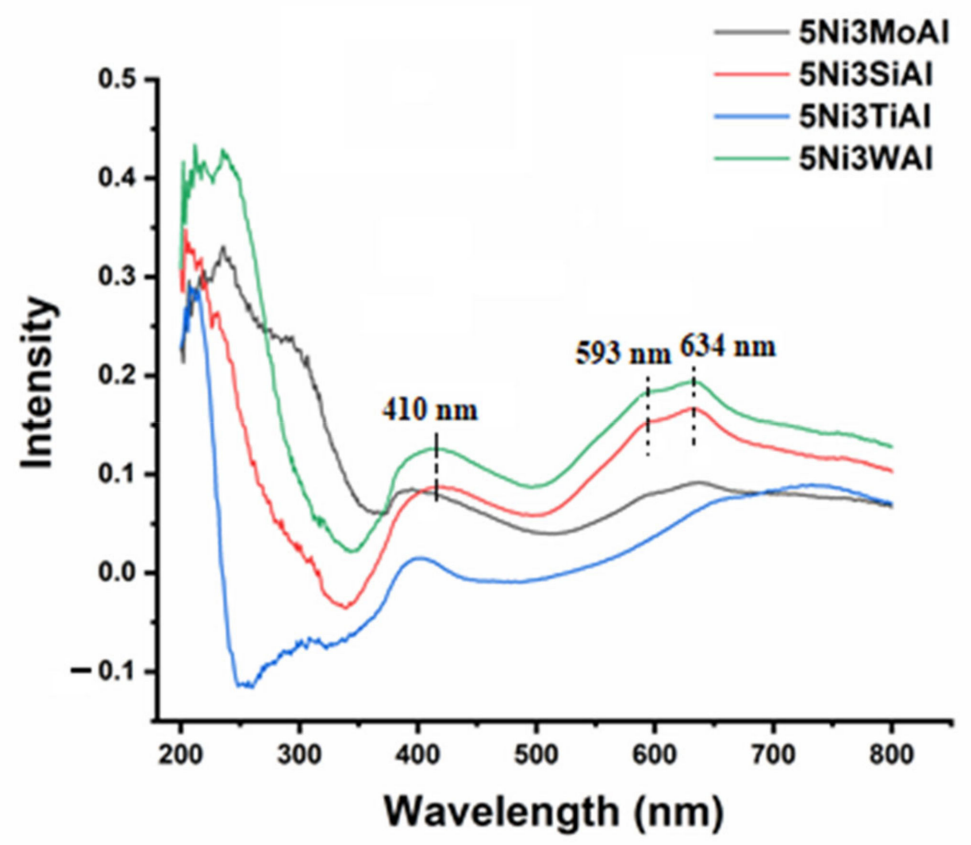

Figure 4. Ultraviolet-visible spectra of different catalyst systems. Peak at $410 \mathrm{~nm}$ is associated with $\mathrm{d}-\mathrm{d}$ transition ${ }^{3} \mathrm{~A}_{2 \mathrm{~g}}(\mathrm{~F}) \rightarrow{ }^{3} \mathrm{~T}_{1 \mathrm{~g}}(\mathrm{P})$ in $\mathrm{Ni}^{2+}$ in an octahedral environment. Peaks at 593 and $634 \mathrm{~nm}$ are associated with the $\mathrm{d}-\mathrm{d}$ transition ${ }^{3} \mathrm{~T}_{1}(\mathrm{~F}) \rightarrow{ }^{3} \mathrm{~T}_{1}(\mathrm{P})$ in $\mathrm{Ni}^{2+}$ in a tetrahedral environment.

In order to clarify further the interaction of $\mathrm{Ti}$ and Mo with the support and with catalytic active sites (NiO), Al (2p, 2s) XPS analysis was conducted on $5 \mathrm{Ni3TiAl}$ and $5 \mathrm{Ni3MoAl}$ (Figure 5A). The Al (2p) XPS spectrum of 5Ni3TiAl was characterized by peaks 
at $74.30 \mathrm{eV}$ and at $119.17 \mathrm{eV}$. These peaks were quite similar to those observed in the Al (2p) XPS spectrum of pure $\gamma-\mathrm{Al}_{2} \mathrm{O}_{3}$ [55]. This evidence indicated that the $\gamma-\mathrm{Al}_{2} \mathrm{O}_{3}$ support doesn't interact with $\mathrm{TiO}_{2}$ and $\mathrm{NiO}$. However, in the presence of molybdenum as a modifier, a substantial shift to lower energy values (to $71.5 \mathrm{eV}$ and $116.34 \mathrm{eV}$ ) was observed for the mentioned peaks in the $\mathrm{Al}(2 \mathrm{p})$ spectra. This shift was indicative of changes in the electronic environment around $\mathrm{Al}$ ions, resulting from an increase in negative charge in the vicinity of $\mathrm{Al}^{3+}$ due to an excess of oxygen atoms around it. It may indicate an oxide enrichment resulting from the formation of $\mathrm{Al}_{2}\left(\mathrm{MoO}_{4}\right)_{3}$ [56]. However, the absence of peak shifts to higher energy in the case of the $\mathrm{Al}(2 \mathrm{p})$ and $\mathrm{Al}(2 \mathrm{~s})$ XPS spectra of $5 \mathrm{Ni} 3 \mathrm{MoAl}$ indicates a poor interaction between $\mathrm{NiO}$ and the $\gamma-\mathrm{Al}_{2} \mathrm{O}_{3}$ support (i.e., the formation of a $\mathrm{NiAl}_{2} \mathrm{O}_{4}$ phase was not observed) [57,58]. Notably, Mo (3d) XPS analysis was also carried out on $5 \mathrm{Ni3MoAl}$ (Figure 5B). The Mo (3d) XPS spectrum of this catalyst showed a doublet peak with maxima at $234.75 \mathrm{eV}$ and $235.8 \mathrm{eV}$, which is attributable to the interaction of $\mathrm{NiO}$ with $\mathrm{MoO}_{\mathrm{x}}$ species [59,60], and a peak at $233.52 \mathrm{eV}$, which is attributable to a strong interaction between $\mathrm{MoO}_{3}$ and $\gamma-\mathrm{Al}_{2} \mathrm{O}_{3}$ or the formation of $\mathrm{Al}_{2}\left(\mathrm{MoO}_{4}\right)_{3}$ [61]. Overall, $5 \mathrm{Ni3TiAl}$ can be said to comprise negligibly interacting species, whereas $5 \mathrm{Ni} 3 \mathrm{MoAl}$ may include species whereby $\mathrm{NiO}$ interacted with $\mathrm{MoO}_{x}$, and $\mathrm{MoO}_{3}$ interacted with $\gamma-\mathrm{Al}_{2} \mathrm{O}_{3}$, although little interaction appeared to exist between $\mathrm{NiO}$ and the $\gamma-\mathrm{Al}_{2} \mathrm{O}_{3}$ support [62].
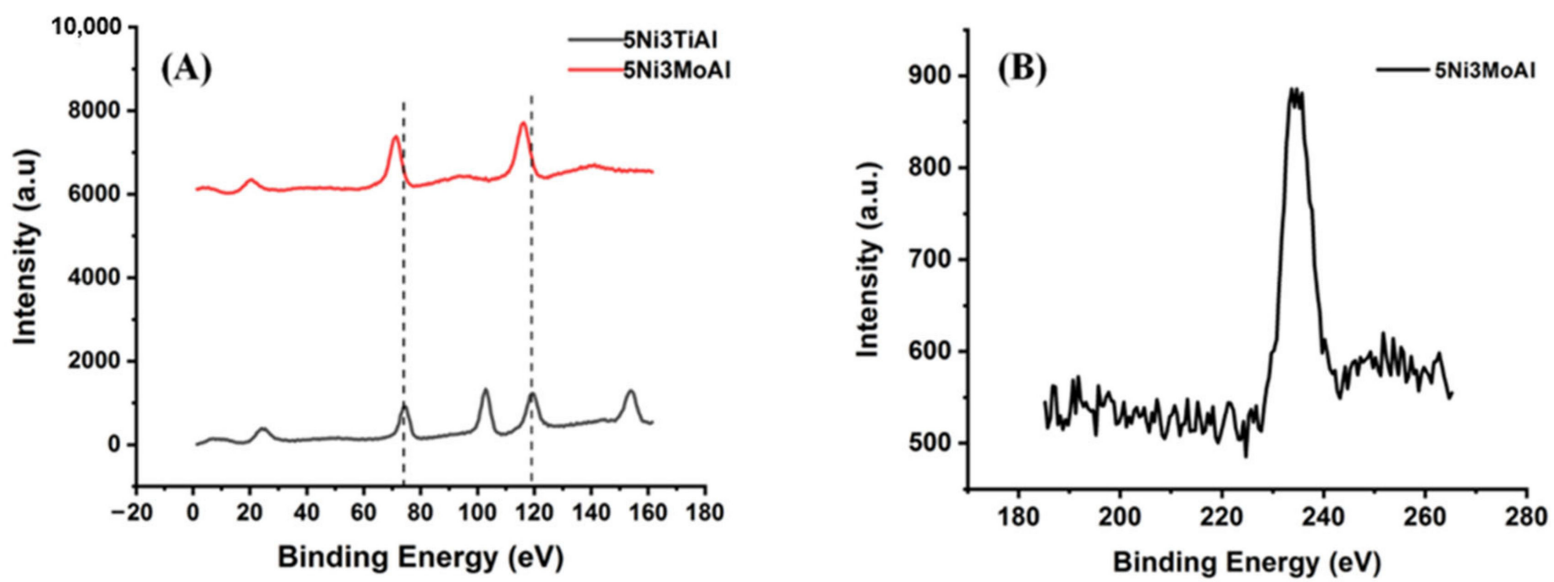

Figure 5. (A) $\mathrm{Al}(2 \mathrm{p}, 2 \mathrm{~s}) \mathrm{X}$-ray photoelectron spectra of catalysts 5Ni3TiAl and 5Ni3MoAl and (B) Mo (3d) X-ray photoelectron spectrum of $5 \mathrm{Ni} 3 \mathrm{MoAl}$.

Till now, catalysts $5 \mathrm{Ni} 3 \mathrm{SiAl}$ and $5 \mathrm{Ni} 3 \mathrm{WAl}$ were thus found to be enriched with $\mathrm{NiO}$ species interacting with the support and the modifier. The tendency of these species to undergo reduction needs, however, to be determined because only reduced nickel species (i.e., metallic nickel) can initiate $\mathrm{CH}_{4}$ decomposition for hydrogen production through $\operatorname{DRM}[63,64]$. In order to determine their reducibility, $\mathrm{H}_{2}$-TPR experiments were carried out for $5 \mathrm{Ni} 3 \mathrm{SiAl}$ and $5 \mathrm{Ni3WAl}$ catalysts (Figure 6). The deconvoluted peak profiles are shown in Figure S4. These reduction peaks can be categorized into four regions; region I 200-400 ${ }^{\circ} \mathrm{C}$, region II $400-700{ }^{\circ} \mathrm{C}$, region III 700-900 ${ }^{\circ} \mathrm{C}$, and region IV 900-1000 ${ }^{\circ} \mathrm{C}$ [65]. The $\mathrm{H}_{2}$-TPR profile of $5 \mathrm{Ni} 3 \mathrm{SiAl}$ was characterized by a low prominent reduction peak in region I and largely overlapped peaks in regions II and III. The less prominent peak in region I was due to reduction of free $\mathrm{NiO}$ species. Region II showed reduction peak for $\mathrm{NiO}$ interacting with the modifier or $\mathrm{NiSiO}_{3}$, whereas region III showed reduction peaks for $\mathrm{NiO}$ interacting with the support or $\mathrm{NiAl}_{2} \mathrm{O}_{4}[55,59]$. Formation of $\mathrm{NiAl}_{2} \mathrm{O}_{4}$ was explained by Scheffer et al. [66]. Nickel ions diffused into the $\mathrm{A}_{2} \mathrm{O}_{3}$ support, where it was coordinated tetrahedrally and octahedrally to form $\mathrm{NiAl}_{2} \mathrm{O}_{4}$. UV of $5 \mathrm{Ni3SiAl}$ sample also detected $\mathrm{Ni}^{+2}$ in tetrahedral and octahedral coordination. On the other hand, the $\mathrm{H}_{2}-\mathrm{TPR}$ profile of $5 \mathrm{Ni} 3 \mathrm{WAl}$ catalyst was characterized by absence of region I peak (for free $\mathrm{NiO}$ ) 
and an additional peak in region IV [67]. The absence of free $\mathrm{NiO}$ species suggested that some interaction was occurred between $\mathrm{NiO}$ and $\mathrm{WO}_{3}$ or $\mathrm{Al}_{2} \mathrm{O}_{3}$ species. Scheffer et al. discussed that from $\mathrm{NiAl}_{2} \mathrm{O}_{4}$ species some of aluminium ions may be replaced and form new $\mathrm{NiO}$ species (or NiWOAl) and the reduction peak of this new $\mathrm{NiO}$ species would be at higher temperature beside reduction peak of $\mathrm{NiAl}_{2} \mathrm{O}_{4}$ species. Thus, additional peak in region IV can be claimed to reduction peaks of NiWOAl species. Further, the reduction peaks in regions II and III were largely overlapped in which region III was more prominent. Region II showed reduction peaks for $\mathrm{NiWO}_{4}$ species, whereas region III showed reduction peaks for $\mathrm{NiAl}_{2} \mathrm{O}_{4}[56,60]$. Overall, it can be said that $5 \mathrm{Ni3SiAl}$ catalyst system had $\mathrm{NiSiO}_{3}$ and $\mathrm{NiAl}_{2} \mathrm{O}_{4}$ species, whereas $5 \mathrm{Ni} 3 \mathrm{WAl}$ catalyst system had $\mathrm{NiWO}_{4}$ and $\mathrm{NiAl}_{2} \mathrm{O}_{4}$ species majorly.
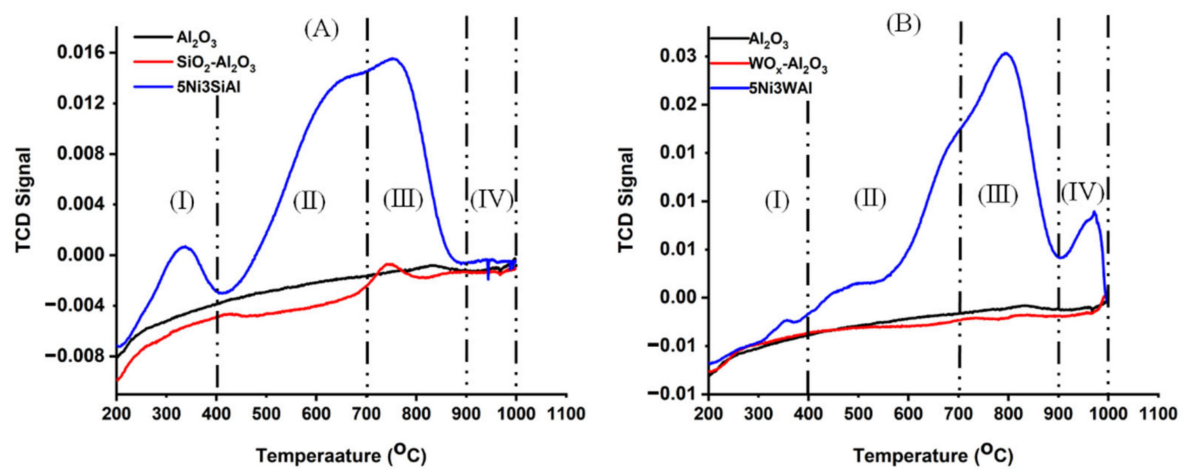

Figure 6. $\mathrm{H}_{2}$ temperature-programmed surface reduction profiles of $(\mathbf{A}) \mathrm{Al}_{2} \mathrm{O}_{3}, 3 \mathrm{SiAl}$, and $5 \mathrm{Ni3SiAl}$ catalysts, and $(\mathbf{B}) \mathrm{Al}_{2} \mathrm{O}_{3}$, $3 \mathrm{WAl}$, and 5Ni3WAl catalysts.

\section{Discussion}

The chief route of $\mathrm{H}_{2}$ production via DRM comprises the dissociation of $\mathrm{CH}_{4}$ over the surface of $\mathrm{Ni}$ (or supported $\mathrm{Ni}$ ) to produce carbon deposits and $\mathrm{H}_{2}$, followed by the oxidation of the carbon deposits by $\mathrm{CO}_{2}$ to produce $\mathrm{CO}\left(\mathrm{CH}_{4}+\mathrm{CO}_{2} \rightarrow \mathrm{CO}+\mathrm{H}_{2}\right)$. Nevertheless, the reverse water gas shift (RWGS) reaction due to a spill over effect of molecular hydrogen, produced over the surface of $\mathrm{Ni},\left(\mathrm{CO}_{2}+\mathrm{H}_{2} \rightarrow \mathrm{CO}+\mathrm{H}_{2} \mathrm{O}\right)$ and the gasification of the carbon deposits by hydrogen gas $\left(\mathrm{C}+2 \mathrm{H}_{2} \rightarrow \mathrm{CH}_{4}\right)$ [68] are not reaction routes that can be ignored. In fact, these parallel reactions can affect $\mathrm{H}_{2}$ yield. Notably, not all parallel reactions, taking place over the catalyst surface, are detrimental to the mean yield of $\mathrm{H}_{2}$. For instance, the presence of water at the catalyst surface (possibly due to RWGS) may contribute to the gasification of carbon deposits, leading to the production of molecular hydrogen and carbon monoxide $\left(\mathrm{C}+2 \mathrm{H}_{2} \mathrm{O} \rightarrow \mathrm{CO}+\mathrm{H}_{2}\right)$, and thus increasing $\mathrm{H}_{2}$ yield.

The dispersion and stability of "Ni-related species" over a support determine the $\mathrm{H}_{2}$ yield of a DRM reaction, taking place over the surface of a catalyst. The $5 \mathrm{Ni3TiAl}$ catalyst was characterized by infrared-active $\mathrm{Ni}-\mathrm{O}$ vibration frequencies close to those of free $\mathrm{NiO}$; in fact, $\mathrm{NiO}$ interacted with the modifier to produce the characteristic peaks of $\mathrm{NiTiO}_{3}$. $\mathrm{UV}-\mathrm{Vis}$ absorption evidence also confirmed the presence of $\mathrm{Ni}^{2+}$ ions in an octahedral environment, in the form of segregated, crystallized, or bulk $\mathrm{NiO}$, and the presence of $\mathrm{Ti}^{4+}$ in both tetrahedral and octahedral environments in $\mathrm{NiTiO}_{3}$. Overall, $5 \mathrm{Ni3TiAl}$ comprised free $\mathrm{NiO}$ and $\mathrm{NiTiO}_{3}$. XPS $\mathrm{Al}(2 \mathrm{p})$ evidence on $5 \mathrm{Ni3TiAl}$ also confirmed the intact nature of $\mathrm{TiO}_{2}$ and $\mathrm{NiO}$ over the $\mathrm{Al}_{2} \mathrm{O}_{3}$ support. The inferior catalytic performance of $5 \mathrm{Ni} 3 \mathrm{TiAl}$ with respect to those of the other systems could be due to the free $\mathrm{NiO}$ species present in it. Use of $5 \mathrm{Ni3TiAl}$ as DRM catalyst was observed to be associated with a $30 \% \mathrm{H}_{2}$ yield at $700{ }^{\circ} \mathrm{C}$ and more than $60 \%$ at $800{ }^{\circ} \mathrm{C}$. The IR spectrum of $5 \mathrm{Ni} 3 \mathrm{MoAl}$ did not include any peaks attributable to the vibration of the $\mathrm{Ni}-\mathrm{O}$ bond of free $\mathrm{NiO}$. The UV-Vis spectrum of $5 \mathrm{Ni} 3 \mathrm{MoAl}$ was indicative of the presence of $\mathrm{Mo}^{6+}$ in octahedral/tetrahedral environments, as environment of $\mathrm{Mo}^{6+}$ in $\mathrm{NiMoO}_{4}$. XPS Mo (3d) evidence on $5 \mathrm{Ni3MoAl}$ 
indicated the presence of a species, whereby $\mathrm{NiO}$ interacted with $\mathrm{MoO}_{\mathrm{x}}$, which was the dominant one, with a smaller prevalence of a species whereby $\mathrm{NiO}$ interacted with the support $\left(\gamma-\mathrm{Al}_{2} \mathrm{O}_{3}\right)$. The absence of free $\mathrm{NiO}$ in $5 \mathrm{Ni3MoAl}$ caused a larger fraction of $\mathrm{Ni}$ interacted species with the modifier $\left(\right.$ as $\left.\mathrm{NiMoO}_{4}\right)$ at the surface than that at $5 \mathrm{Ni} 3 \mathrm{TiAl}$. An increased fraction of species whereby $\mathrm{Ni}$ interacted with $\mathrm{MoO}_{\mathbf{x}}$ (i.e., $\mathrm{NiMoO}_{4}$ ) caused the catalyst to increase in stability and resulted in $>45 \% \mathrm{H}_{2}$ yield of the DRM reaction at $700{ }^{\circ} \mathrm{C}$. At high reaction temperature, about $800{ }^{\circ} \mathrm{C}$, an endothermic feature of DRM reaction promoted enhanced $\mathrm{CH}_{4}$ decomposition at "Ni-interacted species surfaces" as $\mathrm{NiMoO}_{4}$ and $\mathrm{NiTiO}_{3}$ [69]. Therefore, $\mathrm{NiMoO}_{4}$ and $\mathrm{NiTiO}_{3}$ species (in $5 \mathrm{Ni} 3 \mathrm{MoAl}$ and $5 \mathrm{Ni} 3 \mathrm{TiAl}$ catalyst systems, respectively) displayed high catalytic efficiency and thermal stability at high temperatures, with an over $60 \% \mathrm{H}_{2}$ yield of the DRM reaction at $800{ }^{\circ} \mathrm{C}$.

The IR spectra of $5 \mathrm{Ni} 3 \mathrm{SiAl}$ and $5 \mathrm{Ni} 3 \mathrm{WAl}$ were characterized by vibrational frequencies due to a variety species, whereby $\mathrm{NiO}$ interacted with the modifier or the support. $5 \mathrm{Ni} 3 \mathrm{SiAl}$ comprised species, whereby $\mathrm{NiO}$ interacted with the modifier to form $\mathrm{NiSiO}_{3}$ and with the support to produce $\mathrm{NiAl}_{2} \mathrm{O}_{4}$, much like $5 \mathrm{Ni} 3 \mathrm{WAl}$ comprised species, whereby $\mathrm{NiO}$ interacted with the modifier to form $\mathrm{NiWO}_{4}$ and with the support to form $\mathrm{NiAl}_{2} \mathrm{O}_{4}$. UV-Vis absorbance data confirmed the presence of $\mathrm{Ni}^{2+}$ in tetrahedral and octahedral environments in $\mathrm{NiAl}_{2} \mathrm{O}_{4}$ in both catalysts. $\mathrm{H}_{2}$-TPR evidence validated the ability of these "interacting-Ni species" in both $5 \mathrm{Ni} 3 \mathrm{SiAl}$ and $5 \mathrm{Ni} 3 \mathrm{WAl}$ catalyst systems to undergo reduction. As both catalysts comprised a variety of stable interacting-NiO species, they displayed equally high catalytic efficiency. Use of both catalysts in the DRM reaction resulted in $>60 \% \mathrm{H}_{2}$ yield at $700{ }^{\circ} \mathrm{C}$ and $>70 \% \mathrm{H}_{2}$ yield at $800{ }^{\circ} \mathrm{C}$ over $420 \mathrm{~min}$ on stream. Evidence suggested that the $\mathrm{NiSiO}_{3}, \mathrm{NiWO}_{4}$, and $\mathrm{NiAl}_{2} \mathrm{O}_{4}$ mixed oxides present in $5 \mathrm{Ni} 3 \mathrm{SiAl}$ and $5 \mathrm{Ni} 3 \mathrm{WAl}$ were more thermally stable than the $\mathrm{NiTiO}_{3}$ and $\mathrm{NiMoO}_{4}$ mixed oxides present in $5 \mathrm{Ni} 3 \mathrm{TiAl}$ and $5 \mathrm{Ni} 3 \mathrm{MoAl}$, respectively. The catalyst system, composed of $12.5 \mathrm{wt} \% \mathrm{Ni}$ and $12.5 \mathrm{wt} \% \mathrm{Co}$ and supported on $\mathrm{La}_{2} \mathrm{O}_{3}$, showed $31 \%$ and $60 \% \mathrm{H}_{2}$ yield for the catalyst calcined at $700{ }^{\circ} \mathrm{C}$ and $900{ }^{\circ} \mathrm{C}$, respectively [70]. The $5 \mathrm{wt} \% \mathrm{MgO}$-promoted $\mathrm{Ni}-\mathrm{Co} / \mathrm{Al}_{2} \mathrm{O}_{3}-\mathrm{ZrO}_{2}$ nanocatalyst showed about $20 \% \mathrm{H}_{2}$ yield at $650{ }^{\circ} \mathrm{C}$ and $40 \%$ hydrogen yield at $750{ }^{\circ} \mathrm{C}$ [71]. Ni catalysts supported on Gd-doped ceria (prepared by conventional impregnation method) showed $64 \% \mathrm{H}_{2}$ yield [72]. The Sr-promoted $\mathrm{Al}_{2} \mathrm{O}_{3}$ supported Nickel catalyst showed $70 \% \mathrm{H}_{2}$ yield [73]. In our catalyst system, only $3 \mathrm{wt} \%$ promoter of either $\mathrm{W}$ or $\mathrm{Si}$ in $\mathrm{Al}_{2} \mathrm{O}_{3}$-supported nickel catalyst resulted into more than $60 \% \mathrm{H}_{2}$ yield at $700{ }^{\circ} \mathrm{C}$ and more than $70 \% \mathrm{H}_{2}$ yield at $800{ }^{\circ} \mathrm{C}$. In the regeneration study with $5 \mathrm{Ni} 3 \mathrm{SiAl}$ catalyst, the $\mathrm{H}_{2}$ yields after the first and second recycling were 58 and $59 \%$, respectively at at $700{ }^{\circ} \mathrm{C}$. It can be inferred that the catalyst regained nearly all its performance after the removal of carbon deposits by using oxygen (Figure 7).

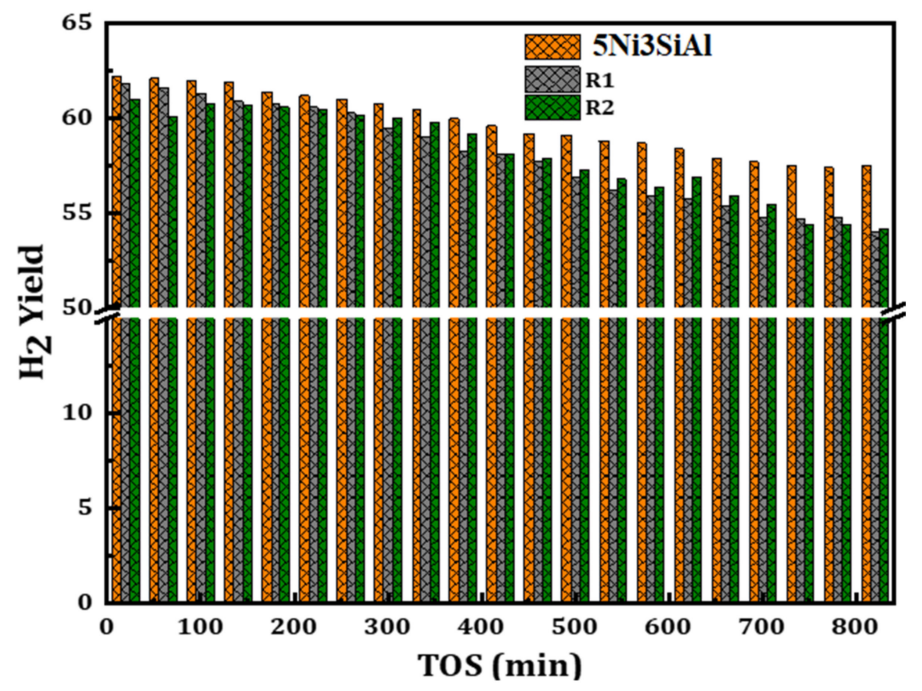

Figure 7. $\mathrm{H}_{2}$ yield over fresh $5 \mathrm{Ni3SiAl}$ catalyst, $\mathrm{H}_{2}$ yield after first cycle (R1), and $\mathrm{H}_{2}$ yield after second cycle (R2). 


\section{Materials and Methods}

\subsection{Catalyst Preparation}

The $5 \mathrm{Ni} 3 \mathrm{MAl}(\mathrm{M}=\mathrm{Si}$, Ti, Mo, or $\mathrm{W})$ catalyst systems were prepared by incipient wetness impregnation, followed by calcination. The detailed procedure for catalyst preparation is described as follows. The required amounts of well-grounded $\gamma-\mathrm{Al}_{2} \mathrm{O}_{3}$ and metal oxides precursors $\left(\left(\mathrm{NH}_{4}\right)_{6} \mathrm{Mo}_{7} \mathrm{O}_{24} \cdot 4 \mathrm{H}_{2} \mathrm{O}\right.$ (Sigma-Aldrich, St. Louis, MO, USA) or $\left(\mathrm{NH}_{4}\right) 10 \mathrm{H}_{2}\left(\mathrm{~W}_{2} \mathrm{O}_{7}\right)_{6}$ (Aldrich)) were mixed together and then crushed mechanically by mortar and pestle. Droplets of deionized $\mathrm{H}_{2} \mathrm{O}$ was added to form a paste. The mechanical mixing was carried out until the dried compact mixture was accomplished. Wetting and drying processes of the solid mixture were done three times. The dried mixture was calcined in a programmable muffle furnace at $600{ }^{\circ} \mathrm{C}$ at the rate $3{ }^{\circ} \mathrm{C} / \mathrm{min}$ for three hours. $\gamma$-Alumina with titania $\left(3.0 \mathrm{wt} \% \mathrm{TiO}_{2} / \gamma-\mathrm{Al}_{2} \mathrm{O}_{3}\right)$ and silica $\left(2.0 \mathrm{wt} \% \mathrm{SiO}_{2} / \gamma-\mathrm{Al}_{2} \mathrm{O}_{3}\right)$ in the form of pellets, were gifts from the Inorganic Chemistry Laboratory, Oxford University, Oxford, UK. Same as the above discussed procedure, the essential amount of $\mathrm{Ni}\left(\mathrm{NO}_{3}\right)_{2} \cdot 6 \mathrm{H}_{2} \mathrm{O}$ along, with doped $\gamma-\mathrm{Al}_{2} \mathrm{O}_{3}$ support were grounded, were made in paste form, and then were dried and calcined. The calcined $5 \mathrm{wt} \% \mathrm{NiO} / 3 \mathrm{wt} \% \mathrm{MOx}-\gamma-\mathrm{Al}_{2} \mathrm{O}_{3}(\mathrm{M}=\mathrm{Ti}, \mathrm{Mo}, \mathrm{W}, \mathrm{Si})$ catalysts were abbreviated as $5 \mathrm{Ni} 3 \mathrm{MAl}(\mathrm{M}=\mathrm{Ti}, \mathrm{Mo}, \mathrm{W}, \mathrm{Si})$.

\subsection{Catalyst Characterization}

Catalysts were characterized by SEM, EDXS, IR, UV-Vis, and X-ray Photoelectron spectroscopy techniques and $\mathrm{H}_{2}$-TPR. The morphology of the catalyst samples was investigated by using a field emission scanning electron microscope (FE-SEM, model: JEOL JSM-7100 F, St. Lucia, Queensland, Australia), furnished with energy dispersive X-ray spectroscopy (EDXS) for surface elemental analysis. The Fourier transform infrared (FTIR) measurements were carried out by using IR Prestige-21 SHMADZU, spectrophotometer, Kyoto, Japan. The spectra were documented in the range $400-4000 \mathrm{~cm}^{-1}$ with $4 \mathrm{~cm}^{-1}$ energy resolution, using $\mathrm{KBr}$ pellet. Ultraviolet-visible measurement was carried out by using V-570 JASCO, Eston, PA, USA) spectrophotometer. The spectra were registered in the range of 200-800 nm wavelength with resolution of $1 \mathrm{~nm}$ at a scanning speed of $200 \mathrm{~nm} / \mathrm{min}$. The XPS was carried out using Thermo Scientific X-ray Photoelectron Spectrometer, Manchester, UK. Monochromatic $\mathrm{Al} \mathrm{K \alpha}(1486.6 \mathrm{eV})$ radiation source operating at a power of $72 \mathrm{~W}$ with a pass energy of $50 \mathrm{eV}$ for high resolution area scans and $200 \mathrm{eV}$ for inspection scans was used. For charge adjustment, a one-point scale with the C1s peak moved to $285.0 \mathrm{eV}$ was used. Temperature-programmed reduction (TPR) was carried out with the Micromeritics AutoChem II, Atlanta, GA, USA. $0.07 \mathrm{~g}$ of the sample (in sample holder) was degassed using argon at $150^{\circ} \mathrm{C}$ for $60 \mathrm{~min}$ and then cooled to $25^{\circ} \mathrm{C}$. Further, it was heated to $800{ }^{\circ} \mathrm{C}$ at the rate of $10^{\circ} \mathrm{C} /$ minute under $10 \% \mathrm{H}_{2}$ in argon flow. The flow rate of $10 \% \mathrm{H}_{2}$ in argon was set at $40 \mathrm{~mL} /$ minute. At the reactor outlet, thermal conductivity detector (TCD) monitors the gas mixture and peaks corresponding to the consumption of $\mathrm{H}_{2}$ as a function of temperature were obtained.

\subsection{Catalytic Reaction}

The reaction was performed at atmospheric pressure in a tubular, stainless steel, fixed-bed micro-reactor (ID $=9 \mathrm{~mm}$ ) (supplied by PID Eng and Tech, Madrid, Spain). $0.10 \mathrm{~g}$ catalyst was reduced under $20 \mathrm{~mL} / \mathrm{min}$ flow of $\mathrm{H}_{2}$ at $800{ }^{\circ} \mathrm{C}$ for $60 \mathrm{~min}$. Now, nitrogen gas was passed through the reactor for $20 \mathrm{~min}$ to eliminate adsorbed $\mathrm{H}_{2}$ at $700{ }^{\circ} \mathrm{C}$. Afterwards, dry reforming of methane was carried out by passing $\mathrm{CH}_{4}, \mathrm{CO}_{2}$, and $\mathrm{N}_{2}$ gas mixture feed at flow rates of 30,30 , and $10 \mathrm{~mL} / \mathrm{min}$ respectively through the catalyst bed. The temperature, pressure and reaction variables were monitored through the reactor panel. GC-2014 (SHIMADZU, Kyoto, Japan) gas chromatograph equipped with Porapak $\mathrm{Q}$ and Molecular Sieve 5A columns and thermal conductivity detector was joined in series/bypass connections to have a whole examination of the reaction products and the feed. For regeneration process, fresh $5 \mathrm{Ni}-3 \mathrm{SiO}_{2}+\mathrm{Al}_{2} \mathrm{O}_{3}$ catalyst is packed in the reactor. The sample was activated with $\mathrm{H}_{2}$ flow of $20 \mathrm{~mL} / \mathrm{min}$ for an hour and then followed by a 
reaction for $820 \mathrm{~min}$ at $700{ }^{\circ} \mathrm{C}$. The spent catalyst is then treated with $10 \mathrm{~mL} / \mathrm{min} \mathrm{O}_{2}$ for $30 \mathrm{~min}$ to remove the deposited carbon. Subsequently, the recycled catalyst was activated with $\mathrm{H}_{2}$ to take care of any oxidized Ni metal during the recycling and thereafter, reaction was performed. Again, the recycling operation was repeated and the reaction carried out the third time.

\section{Conclusions}

The titanium-modified catalyst ( $5 \mathrm{Ni} 3 \mathrm{TiAl}$ ) had free $\mathrm{NiO}$ and $\mathrm{NiTiO}_{3}$ species. Free $\mathrm{NiO}$ species were completely unsuitable for $\mathrm{H}_{2}$ production through DRM. The presence of the free $\mathrm{NiO}$ fraction caused $5 \mathrm{Ni3TiAl}$ to display about $30 \% \mathrm{H}_{2}$ yield at $700{ }^{\circ} \mathrm{C}$. The molybdenum-modified catalyst $(5 \mathrm{Ni} 3 \mathrm{MoAl})$ had no free $\mathrm{NiO}$ species, but had $\mathrm{NiO}$ interacting with $\mathrm{MoO}_{3}$ species or $\mathrm{NiMoO}_{4}$ species, which displayed a moderate catalytic performance of about $45 \% \mathrm{H}_{2}$ yield at $700{ }^{\circ} \mathrm{C}$. Notably, at a higher reaction temperature $\left(800{ }^{\circ} \mathrm{C}\right)$, the endothermic feature of the DRM reaction enhanced $\mathrm{CH}_{4}$ decomposition, and both catalysts displayed a higher but equal efficiency of about $60 \% \mathrm{H}_{2}$ yield. On the other hand, the silicon-modified catalyst (5Ni3SiAl) and tungsten-modified catalyst (5Ni3WAl) were comprised of a variety of thermally stable species, whereby $\mathrm{NiO}$ interacted with the modifier and the support. The $5 \mathrm{Ni} 3 \mathrm{SiAl}$ catalyst system had $\mathrm{NiSiO}_{3}$ and $\mathrm{NiAl}_{2} \mathrm{O}_{4}$ species, whereas the $5 \mathrm{Ni} 3 \mathrm{WAl}$ catalyst system had $\mathrm{NiWO}_{4}$ and $\mathrm{NiAl}_{2} \mathrm{O}_{4}$ species. The sets of mixed oxides present in $5 \mathrm{Ni3SiAl}$ and $5 \mathrm{Ni} 3 \mathrm{WAl}$ were responsible for displaying higher thermal stability and catalytic performance than $5 \mathrm{Ni} 3 \mathrm{TiAl}$ and $5 \mathrm{Ni} 3 \mathrm{MoAl}$. In fact, the $5 \mathrm{Ni} 3 \mathrm{SiAl}$ and $5 \mathrm{Ni} 3 \mathrm{WAl}$ catalyst systems displayed equally high catalytic efficiency of about $60 \% \mathrm{H}_{2}$ yield at $700{ }^{\circ} \mathrm{C}$ and about $70 \% \mathrm{H}_{2}$ yield at $800{ }^{\circ} \mathrm{C}$, over $420 \mathrm{~min}$ on stream. The $5 \mathrm{Ni} 3 \mathrm{SiAl}$ catalyst regained nearly all its activity after the removal of carbon deposits by using oxygen.

Supplementary Materials: The following are available online at https: / www.mdpi.com/2227-9 717/9/1/157/s1, Figure S1: SEM image of different catalyst system; Figure S2: EDX spectra of different catalyst system, Figure S3: Infrared spectroscopy of different catalyst system, Figure S4: Deconvoluted $\mathrm{H}_{2}$ temperature-programmed surface reduction profiles of (A) $5 \mathrm{Ni3SiAl}$ catalyst, and (B) 5Ni3WAl catalyst.

Author Contributions: A.S.A.-F., A.A.I., and S.O.K. synthesized the catalysts, carried out all the experiments and characterization tests, and wrote the manuscript. R.P., F.A.-M., and R.K. prepared the catalyst and contributed to proofreading of the manuscript. F.A.-M., M.L.C., Y.A.A., and A.A.B., writing-review and editing; A.H.F. contributed to the analysis of the data and proofread the manuscript. All authors have read and agreed to the published version of the manuscript.

Funding: The work is supported by the Deanship of Scientific Research programs of King Saud University via project No. RGP-119.

Data Availability Statement: Data is contained within the article.

Acknowledgments: The authors would like to express their sincere appreciation to the Deanship of Scientific Research at King Saud University for funding this research project (\#RGP-119).

Conflicts of Interest: The authors declare no competing interests.

\section{References}

1. Mazloomi, K.; Gomes, C. Hydrogen as an energy carrier: Prospects and challenges. Renew. Sustain. Energy Rev. 2012, 16, 3024-3033. [CrossRef]

2. Balat, M. Potential importance of hydrogen as a future solution to environmental and transportation problems. Int. J. Hydrog. Energy 2008, 33, 4013-4029. [CrossRef]

3. Ni, M.; Leung, D.Y.C.; Leung, M.K.H.; Sumathy, K. An overview of hydrogen production from biomass. Fuel Process. Technol. 2006, 87, 461-472. [CrossRef]

4. Wu, G.; Zhang, C.; Li, S.; Huang, Z.; Yan, S.; Wang, S.; Ma, X.; Gong, J. Sorption enhanced steam reforming of ethanol on Ni-CaO$\mathrm{Al}_{2} \mathrm{O}_{3}$ multifunctional catalysts derived from hydrotalcite-like compounds. Energy Environ. Sci. 2012, 5, 8942-8949. [CrossRef]

5. Clough, P.T.; Boot-Handford, M.E.; Zheng, L.; Zhang, Z.; Fennell, P.S. Hydrogen production by sorption enhanced steam reforming (SESR) of biomass in a fluidised-bed reactor using combined multifunctional particles. Materials 2018, 11, 859. [CrossRef] 
6. Yu, D.; Aihara, M.; Antal, M.J. Hydrogen production by steam reforming glucose in supercritical water. Energy Fuels 1993, 7, 574-577. [CrossRef]

7. Schmieder, H.; Abeln, J.; Boukis, N.; Dinjus, E.; Kruse, A.; Kluth, M.; Petrich, G.; Sadri, E.; Schacht, M. Hydrothermal gasification of biomass and organic wastes. J. Supercrit. Fluids 2000, 17, 145-153. [CrossRef]

8. Osman, A.I.; Meudal, J.; Laffir, F.; Thompson, J.; Rooney, D. Enhanced catalytic activity of Ni on $\mathrm{H}_{-} \mathrm{Al}_{2} \mathrm{O}_{3}$ and $\mathrm{ZSM}^{-5}$ on addition of ceria zirconia for the partial oxidation of methane. Appl. Catal. B Environ. 2017, 212, 68-79. [CrossRef]

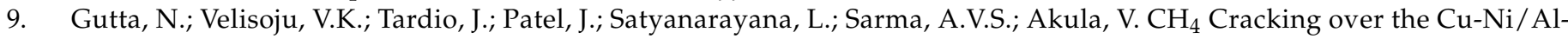
MCM-41 catalyst for the simultaneous production of $\mathrm{H}_{2}$ and highly ordered graphitic carbon nanofibers. Energy Fuels 2019, 33, 12656-12665. [CrossRef]

10. Kumar, R.; Ponnada, S.; Enjamuri, N.; Pandey, J.K.; Chowdhury, B. Synthesis, characterization and correlation with the catalytic activity of efficient mesoporous niobia and mesoporous niobia-zirconia mixed oxide catalyst system. Catal. Commun. 2016, 77, 42-46. [CrossRef]

11. Tomiyama, S.; Takahashi, R.; Sato, S.; Sodesawa, T.; Yoshida, S. Preparation of $\mathrm{Ni} / \mathrm{SiO}_{2}$ catalyst with high thermal stability for $\mathrm{CO}_{2}$-reforming of CH4. Appl. Catal. A Gen. 2003, 241, 349-361. [CrossRef]

12. Al-Fatesh, A.S.A.; Ibrahim, A.A.; Fakeeha, A.H.; Abasaeed, A.E.; Siddiqui, M.R.H. Oxidative $\mathrm{CO}_{2}$ reforming of $\mathrm{CH}_{4}$ over $\mathrm{Ni} / \alpha-\mathrm{Al}_{2} \mathrm{O}_{3}$ catalyst. J. Ind. Eng. Chem. 2011, 17, 479-483. [CrossRef]

13. Kim, D.H.; Kim, S.Y.; Han, S.W.; Cho, Y.K.; Jeong, M.G.; Park, E.J.; Kim, Y.D. The catalytic stability of TiO ${ }_{2}$-shell/Ni-core catalysts for $\mathrm{CO}_{2}$ reforming of $\mathrm{CH}_{4}$. Appl. Catal. A Gen. 2015, 495, 184-191. [CrossRef]

14. Seo, H.O.; Sim, J.K.; Kim, K.D.; Kim, Y.D.; Lim, D.C.; Kim, S.H. Carbon dioxide reforming of methane to synthesis gas over a $\mathrm{TiO}_{2}-\mathrm{Ni}$ inverse catalyst. Appl. Catal. A Gen. 2013, 451, 43-49. [CrossRef]

15. Shah, M.; Mondal, P.; Nayak, A.K.; Bordoloi, A. Advanced titania composites for efficient $\mathrm{CO}_{2}$ reforming with methane: Statistical method vs. experiment. J. CO2 Util. 2020, 39, 101160. [CrossRef]

16. Shah, M.; Bordoloi, A.; Nayak, A.K.; Mondal, P. Effect of Ti/Al ratio on the performance of Ni/ $\mathrm{TiO}_{2}-\mathrm{Al}_{2} \mathrm{O}_{3}$ catalyst for methane reforming with $\mathrm{CO}_{2}$. Fuel Process. Technol. 2019, 192, 21-35. [CrossRef]

17. Xu, Y.; Du, X.H.; Li, J.; Wang, P.; Zhu, J.; Ge, F.J.; Zhou, J.; Song, M.; Zhu, W.Y. A comparison of $\mathrm{Al}_{2} \mathrm{O}_{3}$ and $\mathrm{SiO}_{2}$ supported Ni-based catalysts in their performance for the dry reforming of methane. Ranliao Huaxue Xuebao/J. Fuel Chem. Technol. 2019, 47, 199-208. [CrossRef]

18. Zhou, L.; Li, L.; Wei, N.; Li, J.; Basset, J.-M. Effect of $\mathrm{NiAl}_{2} \mathrm{O}_{4}$ formation on $\mathrm{Ni} / \mathrm{Al}_{2} \mathrm{O}_{3}$ stability during dry reforming of methane. ChemCatChem 2015, 7, 2508-2516. [CrossRef]

19. Shen, D.; Huo, M.; Li, L.; Lyu, S.; Wang, J.; Wang, X.; Zhang, Y.; Li, J. Effects of alumina morphology on dry reforming of methane over $\mathrm{Ni} / \mathrm{Al}_{2} \mathrm{O}_{3}$ catalysts. Catal. Sci. Technol. 2020, 10, 510-516. [CrossRef]

20. Fang, X.; Peng, C.; Peng, H.; Liu, W.; Xu, X.; Wang, X.; Li, C.; Zhou, W. Methane dry reforming over coke-resistant mesoporous $\mathrm{Ni}-\mathrm{Al}_{2} \mathrm{O}_{3}$ catalysts prepared by evaporation-induced self-assembly method. ChemCatChem 2015, 7, 3753-3762. [CrossRef]

21. Medeiros, R.L.B.A.; Figueredo, G.P.; Macedo, H.P.; Oliveira, Â.A.S.; Rabelo-Neto, R.C.; Melo, D.M.A.; Braga, R.M.; Melo, M.A.F. One-pot microwave-assisted combustion synthesis of $\mathrm{Ni}_{-} \mathrm{Al}_{2} \mathrm{O}_{3}$ nanocatalysts for hydrogen production via dry reforming of methane. Fuel 2020, 119511. [CrossRef]

22. Zhao, Y.; Kang, Y.; Li, H.; Li, H. $\mathrm{CO}_{2}$ conversion to synthesis gas: Via DRM on the durable $\mathrm{Al}_{2} \mathrm{O}_{3} / \mathrm{Ni} / \mathrm{Al}_{2} \mathrm{O}_{3}$ sandwich catalyst with high activity and stability. Green Chem. 2018, 20, 2781-2787. [CrossRef]

23. Rahemi, N.; Haghighi, M.; Babaluo, A.A.; Jafari, M.F.; Khorram, S. Non-thermal plasma assisted synthesis and physicochemical characterizations of $\mathrm{Co}$ and $\mathrm{Cu}$ doped $\mathrm{Ni} / \mathrm{Al}_{2} \mathrm{O}_{3}$ nanocatalysts used for dry reforming of methane. Int. J. Hydrog. Energy 2013, 38, 16048-16061. [CrossRef]

24. Fakeeha, A.H.; Bagabas, A.A.; Lanre, M.S.; Osman, A.I.; Kasim, S.O.; Ibrahim, A.A.; Arasheed, R.; Alkhalifa, A.; Elnour, A.Y.; Abasaeed, A.E.; et al. Catalytic performance of metal oxides promoted nickel catalysts supported on mesoporous $\gamma$-Alumina in dry reforming of methane. Processes 2020, 8, 522. [CrossRef]

25. Yao, L.; Galvez, M.E.; Hu, C.; da Costa, P. Mo-promoted Ni/ $\mathrm{Al}_{2} \mathrm{O}_{3}$ catalyst for dry reforming of methane. Int. J. Hydrog. Energy 2017, 42, 23500-23507. [CrossRef]

26. Vroulias, D.; Gkoulemani, N.; Papadopoulou, C.; Matralis, H. W-modified Ni/ $\mathrm{Al}_{2} \mathrm{O}_{3}$ catalysts for the dry reforming of methane: Effect of W loading. Catal. Today 2020, 355, 704-715. [CrossRef]

27. Wei, Q.; Yang, G.; Yoneyama, Y.; Vitidsant, T.; Tsubaki, N. Designing a novel $\mathrm{Ni}-\mathrm{Al}_{2} \mathrm{O}_{3}-\mathrm{SiC}$ catalyst with a stereo structure for the combined methane conversion process to effectively produce syngas. Catal. Today 2016, 265, 36-44. [CrossRef]

28. Al-Fatesh, A.S.; Naeem, M.A.; Fakeeha, A.H.; Abasaeed, A.E. $\mathrm{CO}_{2}$ reforming of methane to produce syngas over $\gamma$ - $\mathrm{Al}_{2} \mathrm{O}_{3}-$ supported Ni-Sr catalysts. Bull. Chem. Soc. Jpn. 2013, 86, 742-748. [CrossRef]

29. Fouskas, A.; Kollia, M.; Kambolis, A.; Papadopoulou, C.; Matralis, H. Boron-modified Ni/ $\mathrm{Al}_{2} \mathrm{O}_{3}$ catalysts for reduced carbon deposition during dry reforming of methane. Appl. Catal. A Gen. 2014, 474, 125-134. [CrossRef]

30. Alipour, Z.; Rezaei, M.; Meshkani, F. Effects of support modifiers on the catalytic performance of $\mathrm{Ni} / \mathrm{Al}_{2} \mathrm{O}_{3}$ catalyst in $\mathrm{CO}_{2}$ reforming of methane. Fuel 2014, 129, 197-203. [CrossRef]

31. Seok, S.H.; Sun, H.C.; Park, E.D.; Sung, H.H.; Jae, S.L. Mn-promoted Ni/ $\mathrm{Al}_{2} \mathrm{O}_{3}$ catalysts for stable carbon dioxide reforming of methane. J. Catal. 2002, 209, 6-15. [CrossRef] 
32. Therdthianwong, S.; Siangchin, C.; Therdthianwong, A. Improvement of coke resistance of $\mathrm{Ni}_{2} / \mathrm{Al}_{2} \mathrm{O}_{3}$ catalyst in $\mathrm{CH}_{4} / \mathrm{CO}_{2}$ reforming by $\mathrm{ZrO}_{2}$ addition. Fuel Process. Technol. 2008, 89, 160-168. [CrossRef]

33. Laosiripojana, N.; Sutthisripok, W.; Assabumrungrat, S. Synthesis gas production from dry reforming of methane over $\mathrm{CeO}_{2}$ doped $\mathrm{Ni} / \mathrm{Al}_{2} \mathrm{O}_{3}$ : Influence of the doping ceria on the resistance toward carbon formation. Chem. Eng. J. 2005, 112, 13-22. [CrossRef]

34. Chein, R.Y.; Fung, W.Y. Syngas production via dry reforming of methane over $\mathrm{CeO}_{2}$ modified $\mathrm{Ni}_{2} / \mathrm{Al}_{2} \mathrm{O}_{3}$ catalysts. Int. J. Hydrog. Energy 2019, 44, 14303-14315. [CrossRef]

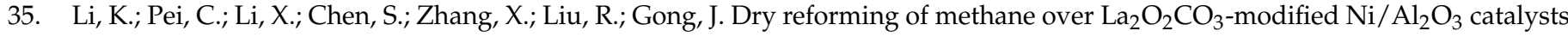
with moderate metal support interaction. Appl. Catal. B Environ. 2020, 264, 118448. [CrossRef]

36. Amin, M.H.; Mantri, K.; Newnham, J.; Tardio, J.; Bhargava, S.K. Highly stable ytterbium promoted Ni $/ \gamma-\mathrm{Al}_{2} \mathrm{O}_{3}$ catalysts for carbon dioxide reforming of methane. Appl. Catal. B Environ. 2012, 119-120, 217-226. [CrossRef]

37. Zhang, Y.; Zhang, S.; Zhang, X.; Qiu, J.; Yu, L.; Shi, C. Ni modified WC x catalysts for methane dry reforming. In Advances in $\mathrm{CO}_{2}$ Capture, Sequestration, and Conversion; American Chemical Society: Washington, DC, USA, 2015; pp. 171-189.

38. Shi, C.; Zhang, S.; Li, X.; Zhang, A.; Shi, M.; Zhu, Y.; Qiu, J.; Au, C. Synergism in NiMoOx precursors essential for $\mathrm{CH}_{4} / \mathrm{CO}_{2}$ dry reforming. Catal. Today 2014, 233, 46-52. [CrossRef]

39. Al-Fatesh, A.S.; Kumar, R.; Kasim, S.O.; Ibrahim, A.A.; Fakeeha, A.H.; Abasaeed, A.E.; Alrasheed, R.; Bagabas, A.; Chaudhary, M.L.; Frusteri, F.; et al. The effect of modifier identity on the performance of Ni-based catalyst supported on $\gamma-\mathrm{Al}_{2} \mathrm{O}_{3}$ in dry reforming of methane. Catal. Today 2020, 348, 236-242. [CrossRef]

40. Vlaev, L.; Damyanov, D.; Mohamed, M.M. Infrared spectroscopy study of the nature and reactivity of a hydrate coverage on the surface of $\gamma-\mathrm{Al}_{2} \mathrm{O}_{3}$. Colloids Surf. 1989, 36, 427-437. [CrossRef]

41. Du, X.; Wang, Y.; Su, X.; Li, J. Influences of $\mathrm{pH}$ value on the microstructure and phase transformation of aluminum hydroxide. Powder Technol. 2009, 192, 40-46. [CrossRef]

42. Dyer, C.; Hendra, P.J.; Forsling, W.; Ranheimer, M. Surface hydration of aqueous $\gamma-\mathrm{Al}_{2} \mathrm{O}_{3}$ studied by Fourier transform Raman and infrared spectroscopy-I. Initial results. Spectrochim. Acta Part A Mol. Spectrosc. 1993, 49, 691-705. [CrossRef]

43. El-Kemary, M.; Nagy, N.; El-Mehasseb, I. Nickel oxide nanoparticles: Synthesis and spectral studies of interactions with glucose. Mater. Sci. Semicond. Process. 2013, 16, 1747-1752. [CrossRef]

44. Zhou, G.; Soo Kang, Y. Synthesis and characterization of the nickel titanate $\mathrm{NiTiO}_{3}$ Nanoparticles in CTAB Micelle. J. Dispers. Sci. Technol. 2006, 27, 727-730. [CrossRef]

45. Vijayalakshmi, R.; Rajendran, V. Effect of reaction temperature on size and optical properties of NiTiO 3 nanoparticles. E-J. Chem. 2012, 9, 282-288. [CrossRef]

46. Umapathy, V.; Neeraja, P.; Manikandan, A.; Ramu, P. Synthesis of $\mathrm{NiMoO}_{4}$ nanoparticles by sol-gel method and their structural, morphological, optical, magnetic and photocatlytic properties. Trans. Nonferrous Met. Soc. China 2017, 27, 1785-1793. [CrossRef]

47. De Moura, A.P.; De Oliveira, L.H.; Rosa, I.L.V.; Xavier, C.S.; Lisboa-Filho, P.N.; Li, M.S.; La Porta, F.A.; Longo, E.; Varela, J.A. Structural, optical, and magnetic properties of NiMoOnanorods prepared by microwave sintering. Sci. World J. 2015, 2015. [CrossRef]

48. Okuno, M.; Zotov, N.; Schmücker, M.; Schneider, H. Structure of $\mathrm{SiO}_{2}-\mathrm{Al}_{2} \mathrm{O}_{3}$ glasses: Combined X-ray diffraction, IR and Raman studies. J. Non-Cryst. Solids 2005, 351, 1032-1038. [CrossRef]

49. Sadjadi, M.S.; Mozaffari, M.; Enhessari, M.; Zare, K. Effects of $\mathrm{NiTiO}_{3}$ nanoparticles supported by mesoporous $\mathrm{MCM}-41$ on photoreduction of methylene blue under UV and visible light irradiation. Superlattices Microstruct. 2010, 47, 685-694. [CrossRef]

50. Salleh, N.F.M.; Jalil, A.A.; Triwahyono, S.; Efendi, J.; Mukti, R.R.; Hameed, B.H. New insight into electrochemical-induced synthesis of $\mathrm{NiAl}_{2} \mathrm{O}_{4} / \mathrm{Al}_{2} \mathrm{O}_{3}$ : Synergistic effect of surface hydroxyl groups and magnetism for enhanced adsorptivity of Pd (II). Appl. Surf. Sci. 2015, 349, 485-495. [CrossRef]

51. Mancheva, M.N.; Iordanova, R.S.; Klissurski, D.G.; Tyuliev, G.T.; Kunev, B.N. Direct mechanochemical synthesis of nanocrystalline $\mathrm{NiWO}_{4}$. J. Phys. Chem. C 2007, 111, 1101-1104. [CrossRef]

52. Torres-Mancera, P.; Ramírez, J.; Cuevas, R.; Gutiérrez-Alejandre, A.; Murrieta, F.; Luna, R. Hydrodesulfurization of 4,6-DMDBT on NiMo and CoMo catalysts supported on $\mathrm{B}_{2} \mathrm{O}_{3}-\mathrm{Al}_{2} \mathrm{O}_{3}$. Catal. Today 2005, 107-108, 551-558. [CrossRef]

53. Carraro, P.; Elías, V.; García Blanco, A.; Sapag, K.; Moreno, S.; Oliva, M.; Eimer, G. Synthesis and multi-technique characterization of nickel loaded MCM-41 as potential hydrogen-storage materials. Microporous Mesoporous Mater. 2014, 191, 103-111. [CrossRef]

54. Forzatti, P.; Mari, C.M.; Villa, P. Defect structure and transport properties of $\mathrm{Cr}_{2}\left(\mathrm{MoO}_{4}\right)_{3}$ and $\mathrm{Al2}(\mathrm{MoO})_{3}$. Mater. Res. Bull. 1987, 22, 1593-1602. [CrossRef]

55. Strohmeier, B.R. Gamma-Alumina $\left(\gamma-\mathrm{Al}_{2} \mathrm{O}_{3}\right)$ by XPS. Surf. Sci. Spectra 1994, 3, 135-140. [CrossRef]

56. Reddy, B.M.; Chowdhury, B.; Smirniotis, P.G. XPS study of the dispersion of $\mathrm{MoO}_{3}$ on $\mathrm{TiO}_{2}-\mathrm{ZrO}_{2}, \mathrm{TiO}_{2}-\mathrm{SiO}_{2}, \mathrm{TiO}_{2}-\mathrm{Al}_{2} \mathrm{O}_{3}$, $\mathrm{SiO}_{2}-\mathrm{ZrO}_{2}$, and $\mathrm{SiO}_{2}-\mathrm{TiO}_{2}-\mathrm{ZrO}_{2}$ mixed oxides. Appl. Catal. A Gen. 2001, 211, 19-30. [CrossRef]

57. Shok, J.; Raju, G.; Reddy, P.S.; Subrahmanyam, M.; Venugopal, A. Catalytic decomposition of $\mathrm{CH}_{4}$ over $\mathrm{NiO}_{-} \mathrm{Al}_{2} \mathrm{O}_{3}-\mathrm{SiO}_{2}$ catalysts: Influence of catalyst preparation conditions on the production of $\mathrm{H}_{2}$. Int. J. Hydrog. Energy 2008. [CrossRef]

58. Kim, K.; Yang, S.; Baek, J.I.; Kim, J.W.; Ryu, J.; Ryu, C.K.; Ahn, D.G.; Shin, K. Distribution of $\mathrm{NiO} / \mathrm{Al}_{2} \mathrm{O}_{3} / \mathrm{NiAl}_{2} \mathrm{O}_{4}$ in the fabrication of spray-dry oxygen carrier particles for chemical-looping combustion. In Advanced Materials Research; Trans Tech Publications: Bach, Switzerland, 2011; Volume 311. [CrossRef]

59. Bianchi, C.L.; Cattania, M.G.; Villa, P. XPS characterization of Ni and Mo oxides before and after 'in situ' treatments. Appl. Surf. Sci. 1993, 70-71, 211-216. [CrossRef] 
60. Anwar, M.; Hogarth, C.A.; Bulpett, R. Effect of substrate temperature and film thickness on the surface structure of some thin amorphous films of MoO3 studied by X-ray photoelectron spectroscopy (ESCA). J. Mater. Sci. 1989, 24, 3087-3090. [CrossRef]

61. Nefedov, V.I.; Firsov, M.N.; Shaplygin, I.S. Electronic structures of $\mathrm{MRhO}_{2}, \mathrm{MRh}_{2} \mathrm{O}_{4}, \mathrm{RhMO}_{4}$ and $\mathrm{Rh}_{2} \mathrm{MO}_{6}$ on the basis of X-ray spectroscopy and ESCA data. J. Electron Spectrosc. Relat. Phenom. 1982, 26, 65-78. [CrossRef]

62. Zingg, D.S.; Makovsky, L.E.; Tischer, R.E.; Brown, F.R.; Hercules, D.M. A surface spectroscopic study of molybdenum-alumina catalysts using x-ray photoelectron, ion-scattering, and Raman spectroscopies. J. Phys. Chem. 1980, 84, 2898-2906. [CrossRef]

63. Schouten, F.C.; Kaleveld, E.W.; Bootsma, G.A. AES-LEED-ellipsometry study of the kinetics of the interaction of methane with Ni(110). Surf. Sci. 1977, 63, 460-474. [CrossRef]

64. Chen, Y.; Hu, C.; Gong, M.; Zhu, X.; Chen, Y.; Tian, A. Chemisorption of methane over $\mathrm{Ni} / \mathrm{Al}_{2} \mathrm{O}_{3}$ catalysts. J. Mol. Catal. A Chem. 2000, 152, 237-244. [CrossRef]

65. Guo, C.; Wu, Y.; Qin, H.; Zhang, J. CO methanation over $\mathrm{ZrO}_{2} / \mathrm{Al}_{2} \mathrm{O}_{3}$ supported $\mathrm{Ni}$ catalysts: A comprehensive study. Fuel Process. Technol. 2014, 124, 61-69. [CrossRef]

66. Scheffer, B.; Molhoek, P.; Moulijn, J.A. Temperature-programmed reduction of $\mathrm{NiO}-\mathrm{WO}_{3} / \mathrm{A}_{2} \mathrm{O}_{3} \mathrm{Hydrodesulphurization}$ Catalysts. Appl. Catal. 1989, 46, 11-30. [CrossRef]

67. Southmayd, D.W.; Contescu, C.; Schwarz, J.A. Temperature-programmed reduction and oxidation of nickel supported on $\mathrm{WO}_{3}-\mathrm{Al}_{2} \mathrm{O}_{3}$ composite oxides. J. Chem. Soc. Faraday Trans. 1993, 89, 2075-2083. [CrossRef]

68. Chung, U.C. Effect of $\mathrm{H}_{2}$ on formation behavior of carbon nanotubes. Bull. Korean Chem. Soc. 2004, 25, 1521-1524. [CrossRef]

69. Al-Fatesh, A.S.; Kumar, R.; Fakeeha, A.H.; Kasim, S.O.; Khatri, J.; Ibrahim, A.A.; Arasheed, R.; Alabdulsalam, M.; Lanre, M.S.; Osman, A.I.; et al. Promotional effect of magnesium oxide for a stable nickel-based catalyst in dry reforming of methane. Sci. Rep. 2020, 10, 1-10. [CrossRef]

70. Fakeeha, A.H.; Khan, W.U.; Al-fatesh, A.S.; Ibrahim, A.A.; Abasaeed, A.E. Production of hydrogen from methane over lanthanum supported bimetallic catalysts. Int. J. Hydrog. Energy 2016, 41, 8193-8198. [CrossRef]

71. Sajjadi, S.M.; Haghighi, M.; Rahmani, F. Dry reforming of greenhouse gases $\mathrm{CH}_{4} / \mathrm{CO}_{2}$ over $\mathrm{MgO}-\mathrm{promoted} \mathrm{Ni-Co} / \mathrm{Al}_{2} \mathrm{O}_{3}-\mathrm{ZrO}{ }_{2}$ nanocatalyst: Effect of $\mathrm{MgO}$ addition via sol-gel method on catalytic properties and hydrogen yield. J. Sol-Gel Sci. Technol. 2014, 70, 111-124. [CrossRef]

72. Gurav, H.R.; Dama, S.; Samuel, V.; Chilukuri, S. Influence of preparation method on activity and stability of Ni catalysts supported on Gd doped ceria in dry reforming of methane. J. CO2 Util. 2017, 20, 357-367. [CrossRef]

73. Ibrahim, A.A.; Fakeeha, A.H.; Al-Fatesh, A.S. Enhancing hydrogen production by dry reforming process with strontium promoter. Int. J. Hydrog. Energy 2014, 39, 1680-1687. [CrossRef] 